This is an electronic reprint of the original article. This reprint may differ from the original in pagination and typographic detail.

Author(s): Ylhäinen, Ilkka

Title: Life-cycle effects in small business finance

Year: $\quad 2017$

Version:

Please cite the original version:

Ylhäinen, I. (2017). Life-cycle effects in small business finance. Journal of Banking and Finance, 77, 176-196. https://doi.org/10.1016/j.jbankfin.2017.01.008

All material supplied via JYX is protected by copyright and other intellectual property rights, and duplication or sale of all or part of any of the repository collections is not permitted, except that material may be duplicated by you for your research use or educational purposes in electronic or print form. You must obtain permission for any other use. Electronic or print copies may not be offered, whether for sale or otherwise to anyone who is not an authorised user. 


\section{Accepted Manuscript}

Life-cycle effects in small business finance

Ilkka Ylhäinen

PII:

S0378-4266(17)30006-7

DOI:

10.1016/j.jbankfin.2017.01.008

Reference:

JBF 5078

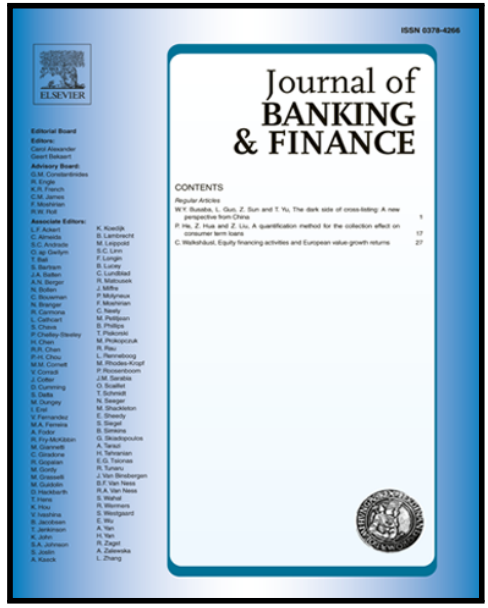

To appear in: Journal of Banking and Finance

Received date: 27 June 2014

Revised date: $\quad 10$ November 2016

Accepted date: $\quad 13$ January 2017

Please cite this article as: Ilkka Ylhäinen, Life-cycle effects in small business finance, Journal of Banking and Finance (2017), doi: 10.1016/j.jbankfin.2017.01.008

This is a PDF file of an unedited manuscript that has been accepted for publication. As a service to our customers we are providing this early version of the manuscript. The manuscript will undergo copyediting, typesetting, and review of the resulting proof before it is published in its final form. Please note that during the production process errors may be discovered which could affect the content, and all legal disclaimers that apply to the journal pertain. 


\title{
Life-cycle effects in small business finance
}

\author{
Ilkka Ylhäinen
}

ETLA, The Research Institute of the Finnish Economy, Arkadiankatu 23 B, FI-00100 Helsinki, FINLAND

Jyväskylä University School of Business and Economics, P.O. Box 35, FI-40014 University of Jyväskylä, FINLAND

Email: ilkka.ylhainen@gmail.com, Tel. +358 447098050

This version: November 10, 2016

\begin{abstract}
This paper studies the life-cycle profiles of small firms' cost and use of credit using a panel of Finnish firms. The choice of method matters for the conclusions drawn about the relationship between firm age and financing costs; the cross-sectional age profiles of financing costs are hump-shaped and consistent with hold-up theories, whereas methods that control for cohort fixed effects demonstrate that the financing costs decrease monotonically as the firms mature. The life-cycle profiles of the use of credit also indicate that firms are more dependent on financial intermediaries in the early periods of their lives. Furthermore, the cohorts born during recessions pay higher financing costs and use smaller amounts of bank loans, even after their creditworthiness is controlled for. The recession cohort effect appears to be more related to the experience of starting-up the firm in the recession than to the CEOs growing up in a recession during their early adulthood.
\end{abstract}


JEL classification: G21; G30

Keywords: life-cycle effects; small business finance; cohort effects

\section{Introduction}

How do the cost of credit and the use of bank finance evolve over the life cycle in small business finance? The theories of financial intermediation, including that of Diamond (1989), predict that informational asymmetries are most severe in the early periods of firms' lives and that such problems diminish over time as the firms mature (see also Boot and Thakor 1994). Diamond (1991) also predicts that firms are more dependent on the monitoring provided by banks early in their lives and switch to other sources of fínance when their reputation improves (see also Berger and Udell 1998). These theoretical frameworks suggest that the cost of credit would decrease and the availability of finance would improve as the firm gets older and does not default. Hold-up theories proposed by Sharpe (1990), Rajan (1992), von Thadden (2004) and Kim et al. (2012) imply an alternative life-cycle profile for financing costs: In a two-period framework, the competition between banks prompts them to offer low borrowing rates to new firms in the first period. The firms become locked in after obtaining the loan, however, as the bank gains an information monopoly over them. The bank then extracts rents from the firms in the form of higher borrowing rates, which implies rising financing costs in the next period. Kim et al. (2012) predict the full life-cycle profile. In their model, there are rising interest rate mark-ups in the early periods of firms' lives and decreasing mark-ups for older firms whose quality has been revealed. 
Previous empirical studies that have analyzed the effects of firm age on the availability and cost of credit have largely used cross-sectional datasets or short panels: ${ }^{1}$ For instance, Petersen and Rajan $(1994,1995)$ utilize cross-sectional data and find a negative correlation between firm age and the cost and use of credit. Hyytinen and Pajarinen (2007) study a panel of Finnish firms over the period 1999-2002 and find that the cost of credit is higher for younger firms even after controlling for the observed and unobserved creditworthiness of the firms. Sakai et al. (2010) suggest that the cost of credit is lower for older firms in their panel of Japanese firms from 1997-2002. Kim et al. (2012) study Norwegian small business data from 2000-2001, analyzing the life-cycle patterns of interest rate mark-ups. They find evidence in favor of lock-in theories; young firms face a low mark-up, whereas there is a rising mark-up for middle-aged firms and a falling mark-up for older firms.

The identification of the life-cycle profiles is difficult, however. To begin with, age effects cannot be distinguished from unobserved firm-specific heterogeneity, including firm quality, in cross-sectional data.Importantly, if there are cohort-specific differences in the firms' cost and use of credit, it is not possible to distinguish them from the age effects in the cross-section. Additionally, in the presence of time- and cohort-specific effects, an identification problem arises in the repeated cross-sections or panel data. Because there is a linear relationship between age, period, and cohort effects (i.e., age=period-cohort), it is not

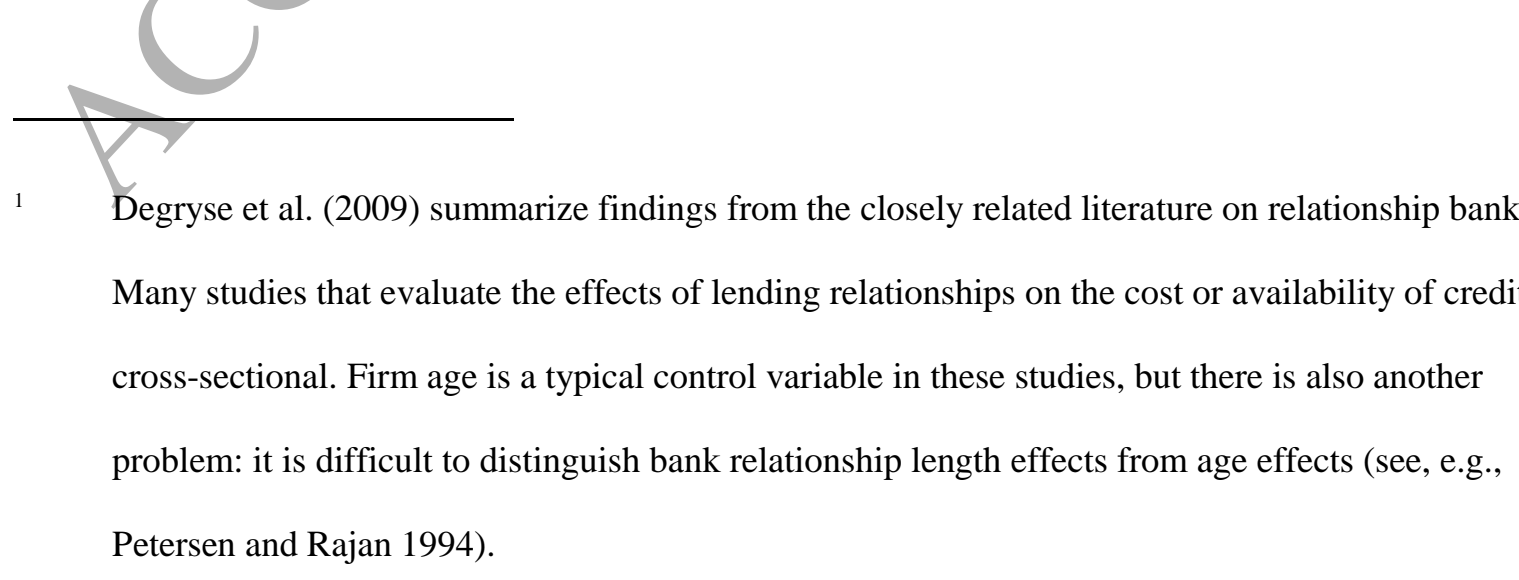


possible to identify all these effects in the same model without some restrictions (see, e.g., Hall et al. 2005). The existence of unobserved firm-specific heterogeneity results in another problem; firm fixed effects remove the cohort effects but do not eliminate the problem of identifying the age and time effects simultaneously (Hall et al. 2005). All these issues would have to be tackled to identify the life-cycle profiles of the cost and use of credit. This study takes several steps in this direction and supplements the scarce corporate finance literature on this largely unexplored issue.

Whether there are significant time and cohort effects in the cost and use of small business loans is a policy-relevant issue that would benefit from further empirical research. Time effects could arise from fluctuations in the macroeconomic and financial environment, while there remains a question whether such effects would affect each age group equally. Holmström and Tirole (1997) predict that poorly capitalized firms, such as start-ups, are most hurt by credit tightening. The empirical evidence indeed suggests that bank-dependent firms are most affected by the tightening of monetary policy and by negative shocks faced by the banking sector (e.g., Gertler and Gillchrist 1994; Kroszner et al. 2007; Dell'Ariccia et al. 2008; Khwaja and Mian 2008; Chava and Purnanandam 2011). The literature on the micro foundations of credit cycles also suggests that financial market imperfections could have significant real effects; shocks to collateral values and their interaction with credit limits could affect borrower net worth and result in large and persistent fluctuations in the output and asset prices (Bernanke and Gertler 1989; Kiyotaki and Moore 1997).

Where could cohort-specific effects arise in small business finance? Building on the analogue from the labor economics literature (see, e.g., Kahn 2010; Oyer 2006), firms established during weak economic times could be perceived as a different quality than otherwise identical firms born during stronger times. The corporate finance literature also 
highlights the adverse effects suffered by bank-dependent borrowers who lose their banking relationships or become otherwise credit-constrained during recessions and financial crises (e.g., Slovin et al. 1993; Kashyap et al. 1994; Kroszner et al. 2007). Corporate managers who started their businesses during a recession may also have less faith in financial markets. Graham and Narasimham (2004) find that publicly listed U.S. firms that experienced the U.S. Great Depression use less leverage in the 1940s than other firms. Malmendier et al. (2011) suggest that the CEOs of publicly listed U.S. firms who grew up during the Great Depression lean excessively towards internal finance. Schoar and Zuo (2016) observe in their sample of publicly listed U.S. firms that CEOs who started their careers during recessions use more conservative management approaches, including the lower use of leverage. Malmendier and Nagel (2011) provide complementary evidence suggesting that macroeconomic shocks faced earlier in life could affect the financial risk taking of individuals (see also Knüpfer, Rantapuska and Sarvimäki 2016). Giuliano and Spilimbergo (2014) study the impressionable years hypothesis of social psychology, which suggests that economic and political beliefs are formed during the early adulthood and change only slowly after this critical age. They indeed find that the experience of a recession during the critical years of early adulthood has a longlasting effect on the beliefs and preferences of individuals.

The development of the financial markets and improvements in the informational environment could also be potential sources of cohort effects. For instance, the younger cohorts may benefit from improved bank screening technologies, such as credit scoring and the better availability of high-quality credit information (cf. Petersen and Rajan 2002). The improved availability of borrower-specific information from credit bureaus and credit rating agencies could reduce adverse selection, lower the informational rents banks can extract from borrowers, and improve borrower discipline (Jappelli and Pagano 1993, 2000; Padilla and 
Pagano 1997, 2000). The development of financial markets would generally predict the availability of lower cost external finance for firms (Rajan and Zingales 1998).

This study analyzes the life-cycle profiles of financing costs and the use of credit using a large register-based panel of Finnish firms. This new dataset covers the period 1999-2013 and provides a longer and more recent study period than used in the previous studies. The firms in the sample are on average very small - most of them are micro firms - and thus provide an effective testing ground for the theories of asymmetric information. In addition, the Finnish financial system is bank-based, an institutional setup that provides a good comparison point to the studies on more market-orientated financial systems, including the U.S system. The study also differentiates itself from the previous literature by paying careful attention to disentangling age, period, and cohort effects. This identification problem has been largely ignored in the previous corporate finance studies, which have relied on crosssectional data and short panels. The current study utilizes a number of alternative methods to overcome the identification problem. In particular, the life-cycle profiles estimated from the cross-sectional data and models are compared to more appropriate methods that control for cohort or firm fixed effects. An important feature of the current dataset is that it also includes the widely used commercial credit scores of the firms in the dataset. Thus, the observed creditworthiness of the firms can be controlled in the analysis among other key variables.

The findings of the paper suggest that the choice of the method affects the conclusions drawn about the relationship between the firm age and the financing costs. The crosssectional age profiles of financing costs are hump-shaped and consistent with hold-up theories. In contrast, the regressions that control for the cohort or firm fixed effects suggest that the financing costs decrease monotonically as the firms mature, in line with the prediction of Diamond (1989). The findings suggest that these differences in the age profiles 
relate to cohort effects. After controlling for the cohort or firm fixed effects that are essential in capturing the firm-specific heterogeneity, the baseline findings point more towards the reputational theories than towards the hold-up theories as an explanation for the life-cycle profiles of financing costs. Moreover, the age profiles of the use of credit indicate that firms are more dependent on financial intermediaries in the early periods of their lives.

A few main findings are made about the cohort effects. First, the younger cohorts face lower costs of credit than the older cohorts. While the source of this cohort effect was not formally tested, the longer-term trend of decreasing cohort-speeific financing costs would generally appear to be consistent with the hypothesis about the improvements in the financial system and the information environment. Second, the findings suggest that cohorts born in recessions, particularly the Finnish Great Depression and the banking crisis of the 1990s and the more recent international financial crisis, face hígher financing costs and use a smaller amount of bank loans in a persistent fashion. This effect is robust to controlling for the observed creditworthiness of the firms with commercial credit scores. The recession-born firm effect is larger for younger CEOs, in line with the prediction that macroeconomic shocks have a more significant effect on young individuals. However, the recession cohort effect appears to be more related to the experience of starting-up the firm in the recession than to the CEOs growing up in a recession during their early adulthood. Overall, these findings suggest that recessions and periods of financial instability could have a lasting impact on the perceived riskiness of the firms and their use of external finance in the future.

The remainder of the paper is organized as follows: Section 2 presents the dataset. Section 3 provides an overview of the empirical methods. Sections 4-6 present the empirical results, and Section 7 concludes. 


\section{Data}

\subsection{Data sources}

The dataset used in this study consists of a register-based panel of Finnish firms from the period 1999-2013. The panel design is unbalanced and therefore allows firms to enter into and exit from the sample (e.g., because of bankruptcy) during the study horizon. The dataset consists of financial statements and related data compiled from official sources by Asiakastieto ltd, an information provider of firm and credit data in Finland. The financial statement data originate from the Finnish Trade Register, an official register of Finnish firms. The dataset also contains the commercial credit scores and associated credit ratings of the firms computed by Asiakastieto. Several macroeconomic variables were matched to the dataset, including the aggregate country-level unemployment rates, GDP growth, house prices, and consumer prices, which were obtained from the databases of Statistics Finland. The Finnish government bond yields were obtained from the database of the Bank of Finland.

The estimation sample is restricted to non-farm and non-financial corporations. This restriction helps avoid issues such as differences in the accounting practices from affecting the results. ${ }^{2}$ The sample is restricted to small businesses by removing firm-year observations exceeding the EU-level small and medium-sized firm thresholds in terms of employment

2 The majority of the observations (i.e., about 98\%) in the original data belong to corporations. The

following industries are dropped from the sample: Agriculture, forestry and fishing; Financial and insurance activities; Electricity, gas, steam and air conditioning supply; Water supply; sewerage, waste management and remediation activities; Activities of membership organizations; Operation of dwellings and residential real estate; Management activities of holding companies; Public administration and defense; compulsory social security; Activities of extraterritorial organizations and bodies; Industry unknown. 
(less than 250 persons), net sales (50 million euros) or total assets (43 million euros). The estimation sample concentrates on the cohorts born between the periods 1960-2012. Because the informational asymmetries are likely to be the most relevant for relatively young firms, the firms older than 40 years are dropped from the sample. This helps to control for the additional noise caused by the relatively few firm observations among the older firms in the age distribution. ${ }^{3}$ Firm observations with negative total assets are dropped from the sample. The CEO characteristics focus on working-age CEOs younger (or not older) than 74 years.

\subsection{Variable definitions}

The study analyzes the life-cycle profiles of small firms' cost and use of credit. These measures are computed from the financial statement data. Financing costs are measured as financial expenses at period $t$ divided by the average outstanding interest-bearing debt between periods t-1 and $\mathrm{t}^{4}$ Bank debt is a ratio of outstanding debt from financial institutions scaled by total assets at period $t^{5}$

3 In the robustness tests, start-up firms born potentially because of mergers or spinoffs were removed from the sample based on a mechanical rule of dropping firms with net sales larger than or equal to the $99^{\text {th }}$ percentile of the start-up firm distribution, which includes the firms of age one year or less. This did not materially change the estimated life-cycle profiles.

The financing cost measure is computed only for the observations in which the financial expenses are positive and non-zero. Indeed, it would be conceptually problematic to evaluate the effects of firm age on the financing costs if the firms have no financial expenses (see, e.g., Hyytinen and Pajarinen 2007).

5 For convenience, loans obtained from financial institutions are referred to as bank financing in the text. This seems a reasonable shortcut definition because bank loans represent a major fraction of 
The previous empirical banking literature suggests that age, size, and type of business are three key determinants of firms that rely on banking relationships: In particular, younger, smaller, and less transparent firms that have more intangible assets are more difficult to screen successfully (see, e.g., Freixas and Rochet 2008, 105). Firm age is a key variable of interest in this study. It is also a measure that has been considered as a good proxy for informational asymmetries in the previous corporate finance literature (e.g., Beck et al. 2006; Hyytinen and Pajarinen 2008; Hyytinen and Väänänen 2006). The firm age is calculated by subtracting the year of birth from the current year. The year of birth is defined as the year the firm was registered in the Finnish Trade Register. The current year refers to the year of the financial statement. ${ }^{6}$ Firm size is proxied with $\ln ($ Sales $)$, which is a natural logarithm of net sales at $\mathrm{t}-1$. Tangibility is a proxy for collateralizable assets and defined as a ratio of fixed to total assets at t-1. Profitability is measured as earnings before interest, taxes, depreciation, and amortization divided by total assets at $\mathrm{t}-1$. Credit score measures the observed creditworthiness of the firms (i.e., the probability of default) at t-1 computed by Asiakastieto. This commercial credit score is defined at the interval 3-100, where low values indicate high creditworthiness and high values indicate low creditworthiness. The credit scores for 2006 are not available in the data because of changes in the dataset; therefore, values from the previous period are used in that particular year. If the values from the previous period are not

the financing obtained from financial institutions in Finland (see, e.g., Business Financing Survey 2009). Note that this measure can generally also cover financing from other financial institutions, including special financing institutions. Furthermore, the non-use of bank loans does not necessarily indicate supply side constraints, simply because some firms may have no demand for bank loans.

6 In some instances, the method of calculating the firm age resulted in negative ages, in which case, the observation was dropped. 
available, the values from the following period are used instead to avoid losing startup firms. ${ }^{7}$ Recession-born is a dummy that takes a value equal to one if the firm is born during a period of negative real GDP growth (years 1991, 1992, 1993, 2009, and 2012) and zero otherwise. The information on defaults and bankruptcies is available in the data since 2005. Default measures the number of missed debt payments at $\mathrm{t}-1$. Bankruptcy is an indicator for bankruptcy applications made by the debtor or creditors at $\mathrm{t}$.

The entrepreneur-specific information is obtained from the social security numbers of the CEOs of the firms. The entrepreneur's age is controlled with $\ln (C E O$ age $)$, which is a natural logarithm of the age of the CEO. It is computed as a difference between the current year and the birth year obtained from the social security number. The gender of the entrepreneur is controlled with an indicator Female, taking a value one for female CEOs, and zero otherwise. The gender is obtained from the first three numbers of the final part of the social security number, where odd and even numbers define male and female, respectively. Recession-grown CEO is an indicator for CEOs who experienced a recession during the impressionable years of their early adulthood (i.e., between 18 and 25 years). ${ }^{8}$ The social security numbers are available in the data since 2003, although not for all entrepreneurs. ${ }^{9}$

7 The transition matrices of the credit ratings and the serial correlations of the credit scores indicate

that there is considerable persistence in the creditworthiness of the firms. This suggests that the above approach provides a reasonable solution for the missing data issue.

8 Since the study focuses on working-age CEO cohorts whose early adulthood took place in the postwar period, the recession years for this measure are the same as for the firm-level recession-born indicator (i.e., the first negative post-war GDP growth took place in 1991; see, e.g., Hjerppe 1989, 2010). That is, the CEO cohorts born in 1966-1975 and 1984-1995 are defined as recession-grown 
The industry-specific characteristics are controlled using two-digit-level industry dummies. There was a change in the industry classifications in 2008 that affects the classifications used in the data. Specifically, firms that existed in the earlier periods but did not exist anymore in 2008 were classified using the previous standard industrial classification (SIC) version. In the following analysis, industries are classified using SIC 2008 when available and using SIC 2002 in the other instances. A dummy for the firms classified using SIC 2002 is included in the regressions to take into account the scale differences in the different versions of the classifications. Regional dummies measured at the two-digit zipcode level based on the firms' addresses are also included in the regressions. Petersen and Rajan (1995) argue that the life-cycle profiles of financing costs could differ between competitive and non-competitive markets because monopolistic banks may be able to subsidize younger firms. It is also worth taking into account that firms in certain areas of the country are eligible for more government subsidies than others, which could be reflected in the financing costs. The regionat fixed effects provide a way to control for the fixed regional characteristics, including these local credit market characteristics.

The macroeconomic control variables used in some of the specifications are defined as follows: Unemployment measures the country-level unemployment rates at period t. Term spread measures the difference in the yields of the Finnish government bonds of the maturity

CEOs for the Finnish Great Depression and the more recent recession that accompanied the international financial crisis, respectively, in line with the impressionable years hypothesis.

$9 \quad$ One potential reason for missing social security numbers (besides not having a formal CEO) could be foreign CEOs, who do not have a Finnish social security number. In a few thousand instances the social security numbers in the data only have a birth date and not the final part defining the gender. 
of ten and five years at period t, respectively. House prices growth measures the growth of the house prices index defined in natural logarithms between periods t-1 and t. CPI growth measures the growth of consumer prices defined in natural logarithms between periods $\mathrm{t}-1$ and t. GDP growth measures the growth of gross domestic product defined in natural logarithms between periods $\mathrm{t}-1$ and $\mathrm{t}$. The time fixed effects used in other panel specifications provide an alternative way to control for the macroeconomic conditions of the periød.

To avoid issues related to large outliers, some of the key variables are trimmed or winsorized as follows: Financing costs are trimmed at the $5^{\text {th }}$ and $95^{\text {th }}$ percentile of the distribution because of the large outliers typical for this kind of data. ${ }^{10}$ In this type of measure, outliers could arise, for example, because of large changes in the amount of outstanding debt near the end of the period that are not reflected in the financial expenses accrued over the year (see, e.g., Bernhardsen and Larsen 2003; Kim et al. 2012). ${ }^{11}$ Bank debt is trimmed at the values below zero and above one. Profitability and Tangibility are winsorized at the 1st and

This drops out (erroneous) negative values, some unrealistically small (but positive) values and very large values. Note that this trimming does not remove any zero values, which are already removed in the process of forming the variable. The trimming percentiles as such are more conservative than the ones used by Kim et al. (2012), who remove observations outside the $10^{\text {th }}$ and $90^{\text {th }}$ percentiles. In the robustness tests, Financing costs were alternatively trimmed at the $1^{\text {st }}$ and $99^{\text {th }}$ percentile of the distribution, which resulted in similar albeit noisier profiles of financing costs. However, this alternative trimming strategy cannot completely deal with some unreasonably large values despite setting the value of interest-bearing debt to missing when its value was non-positive (zero) in either of the two subsequent periods used in the computation of the measure. It remains possible that the financial expenses could reflect foreign exchange losses, while this issue is probably less acute among domestically orientated small businesses. 
99th percentiles to ensure that outliers in the control variables are not confounding the results. These control variables are winsorized rather than trimmed to avoid any unnecessary loss of observations.

\subsection{Descriptive statistics}

The panel statistics are provided in table A1 in the appendix. They indicate that the number of firms covered by the data has increased over the years. The descriptive statistics are provided in table 1 . The statistics are reported separately for the estimation samples analyzing financing costs and bank debt because of different sample sizes. ${ }^{12}$ The baseline samples cover the 1999-2013 period. The average financing costs shown in panel A are 5.3\% p.a. (median: 4.4\%). The firm-level statistics shown in panel B are as follows: The mean percentage of bank debt is $13.7 \%$ based on the definition of a ratio of loans from financial institutions to total assets. The firms in the sample are on ayerage a bit more than 13 years old. The average net sales are approximately 1.2 million euros, whereas the median net sales are approximately 280000 euros. The number of employees, not reported in the table, confirms that the firms are mostly very small; the average number of workers is about eight persons, while the median is only three persons. The average ratio of fixed assets to total assets in the balance sheet is 0.255 . The profitability measure indicates that the average return on assets before interest, taxes, depreciation and amortization is $17.4 \%$. The average credit score suggests that the firms are on average rated as A+ (i.e., "Satisfactory+") on the seven-step rating scale 
AAA, AA+, AA, A+, A, B, C. The indicator for recession-born cohorts indicates that $14.7 \%$

of the firm-year observations belong to firms born during the periods of negative real GDP growth. The average and median number of missed debt payments are 0.130 and zero, respectively, whereas $0.3 \%$ of the firm-year observations belong to firms applied to bankruptcy. The mean CEO age is 49 years, whereas $16 \%$ of the firm-year observations belong to firms with female CEOs.

Table 1 Descriptive statistics Panel A: Financing cost sample

\begin{tabular}{|c|c|c|c|c|c|c|c|c|}
\hline variable & mean & sd & $\min$ & p25 & p50 & p75 & $\max$ & NT \\
\hline \multicolumn{9}{|c|}{ Sample period: $1999-2013$} \\
\hline Financing costs & 0.053 & 0.038 & 0.006 & 0.028 & 0.044 & 0.065 & 0.238 & 435690 \\
\hline Age & 13.268 & 8.498 & 1.000 & 6.000 & 12.000 & 19.000 & 40.000 & 435690 \\
\hline $\ln$ (Sales) & 13.000 & 1.545 & 2.708 & 11.964 & 12.941 & 13.988 & 17.727 & 435690 \\
\hline Tangibility & 0.316 & 0.281 & 0.000 & 0.066 & 0.235 & 0.529 & 0.979 & 435690 \\
\hline Profitability & 0.163 & 0.257 & -1.500 & 0.060 & 0.162 & 0.287 & 0.967 & 435690 \\
\hline Credit score & 0.313 & 0.212 & 0.030 & 0.160 & 0.270 & 0.410 & 1.000 & 435690 \\
\hline Recession-born & 0.144 & & 0.000 & 0.000 & 0.000 & 0.000 & 1.000 & 435690 \\
\hline Unemployment & 0.082 & 0.008 & 0.064 & 0.077 & 0.082 & 0.088 & 0.098 & 435690 \\
\hline Term spread & 0.007 & & 0.001 & 0.005 & 0.009 & 0.010 & 0.012 & 435690 \\
\hline House prices growth & 0.042 & 0.030 & -0.005 & 0.016 & 0.053 & 0.071 & 0.084 & 435690 \\
\hline CPI growth & 0.018 & 0.011 & 0.001 & 0.009 & 0.015 & 0.028 & 0.039 & 435690 \\
\hline GDP growth & 0.030 & 0.032 & -0.068 & 0.015 & 0.033 & 0.049 & 0.078 & 435690 \\
\hline \multicolumn{9}{|c|}{ Sample period: $2005-2013$} \\
\hline Default & 0.185 & 1.727 & 0.000 & 0.000 & 0.000 & 0.000 & 135.000 & 273738 \\
\hline Bankruptcy & 0.005 & 0.074 & 0.000 & 0.000 & 0.000 & 0.000 & 1.000 & 273738 \\
\hline \multicolumn{9}{|c|}{ Sample period: 2003-2013 } \\
\hline $\ln (\mathrm{CEO}$ age $)$ & 3.849 & 0.214 & 2.890 & 3.714 & 3.871 & 4.007 & 4.304 & 254737 \\
\hline Female & 0.140 & 0.347 & 0.000 & 0.000 & 0.000 & 0.000 & 1.000 & 254737 \\
\hline Recessión-grown CEO & 0.253 & 0.435 & 0.000 & 0.000 & 0.000 & 1.000 & 1.000 & 254737 \\
\hline
\end{tabular}

Panel B: Bank debt sample

\begin{tabular}{lcccccccc}
\hline variable & mean & sd & min & p25 & p50 & p75 & max & NT \\
\hline Sample period: & $1999-2013$ & & & & & & & \\
Bank debt & 0.137 & 0.219 & 0.000 & 0.000 & 0.000 & 0.217 & 1.000 & 746299 \\
Age & 13.435 & 8.456 & 1.000 & 6.000 & 12.000 & 19.000 & 40.000 & 746299
\end{tabular}




\begin{tabular}{|c|c|c|c|c|c|c|c|c|}
\hline $\ln ($ Sales $)$ & 12.607 & 1.646 & 2.197 & 11.495 & 12.545 & 13.665 & 17.727 & 746299 \\
\hline Tangibility & 0.255 & 0.264 & 0.000 & 0.039 & 0.154 & 0.416 & 0.979 & 746299 \\
\hline Profitability & 0.174 & 0.283 & -1.500 & 0.054 & 0.171 & 0.312 & 0.967 & 746299 \\
\hline Credit score & 0.283 & 0.196 & 0.030 & 0.140 & 0.250 & 0.370 & 1.000 & 746299 \\
\hline Recession-born & 0.147 & 0.354 & 0.000 & 0.000 & 0.000 & 0.000 & 1.000 & 746299 \\
\hline Unemployment & 0.082 & 0.008 & 0.064 & 0.077 & 0.082 & 0.088 & 0.098 & 746299 \\
\hline Term spread & 0.008 & 0.003 & 0.001 & 0.005 & 0.009 & 0.010 & & 746299 \\
\hline House prices growth & 0.042 & 0.030 & -0.005 & 0.016 & 0.053 & 0.071 & & 746299 \\
\hline CPI growth & 0.018 & 0.011 & 0.001 & 0.009 & 0.015 & 0.028 & & 746299 \\
\hline GDP growth & 0.029 & 0.032 & -0.068 & 0.015 & 0.033 & 0.049 & & 746299 \\
\hline \multicolumn{9}{|c|}{ Sample period: 2005-2013 } \\
\hline Default & 0.130 & 1.476 & 0.000 & 0.000 & 0.000 & & 00( & 500074 \\
\hline Bankruptcy & 0.003 & 0.057 & 0.000 & 0.000 & 0.000 & & 1.000 & 500074 \\
\hline \multicolumn{9}{|c|}{ Sample period: 2003-2013 } \\
\hline $\ln (\mathrm{CEO}$ age $)$ & 3.867 & 0.216 & 2.890 & 3.738 & 3.89 & 4.025 & 4.304 & 431666 \\
\hline Female & 0.160 & 0.366 & 0.000 & 0.000 & & 0.000 & 1.000 & 431666 \\
\hline Recession-grown CEO & 0.237 & 0.425 & 0.000 & 0.000 & 0.000 & 0.000 & 1.000 & 431666 \\
\hline
\end{tabular}

The table reports the descriptive statistics for the unbalanced panel of Finnish corporations. Panels A and B report separate statistics for the estimation samples analyzing financing costs and bank debt, respectively. The statistics include mean, standard deviation, minimum, 25th percentile, 50th percentile, 75th percentile and the maximum of the variables, respectively. $N T$ is the number of firm-year observations.

\section{Empirical approach}

\subsection{Identification of age, period, and cohort effects}

The fundamental problem of identifying age, period, and cohort effects is well known in the economics literature, but the issue has been left almost unaddressed in the corporate finance literature. $^{13}$ The identification problem is stated as follows: because there is a linear

13 Sakai et al. (2010) provide a short discussion about the issue. Otherwise, the identification problem has been largely ignored in the empirical corporate finance research. Notably, Petersen and Rajan $(1995,419)$ claim that they can identify the age effects in cross-sectional data under certain assumptions, namely the stationarity of the survival process of firms. 
relationship between the age, period, and cohort effects (based on the identity: Age $=$ Period - Cohort $)$, it is not possible to identify all of them in the same model without some restrictions (see, e.g., Hall et al. 2005). This makes it difficult to evaluate the life-cycle profiles of small firms' cost and use of credit. Indeed, the modeling and identification of such relationships is complicated for an obvious reason: it is impossible to observe two firms (or entrepreneurs) at the same point in time that have the same age but who are born at different periods (cf. Hall et al. 2005). This is problematic because the otherwise identical firms that belong to different cohorts could face very different economic environments. This problem could be acute, for instance, if the stage of the business cycle during which the firm is born has persistent effects on the firm for the rest of the periods. The identification problem is equally complicated if the younger cohorts face fundamentally different financial environments than the older cohorts. Such cohort-specific differences could arise because of certain factors, including differences in the availability of credit information, developments in bank screening methods and general developments in the financial system.

The previous economic literature suggests several solutions to the identification problem in various other contexts. Deaton and Paxson (1992) and Attanasio (1998) identify the life-cycle effects as follows: they use a polynomial of age or age dummies, together with cohort effects, and normalize the time dummies to sum to zero and to be orthogonal to a linear time trend (see also Deaton 1997). Hall et al. (2005) analyze the identification problem related to the life-cycle effects in another context and discuss various approaches for addressing the issue, such as testing which effects are present and constraining some of the cohort, time or age dummies to have equal effects in the same dimension. They also highlight the problems that arise in the presence of unobserved firm-specific heterogeneity; for example, including firm fixed effects removes the cohort effects and renders some of the 
cohort-based approaches unavailable. However, the firm fixed effects do not eliminate the problem of identifying the age and period effects simultaneously (cf. Hall et al. 2005).

In the context of corporate finance, Sakai et al. (2010) argue that the empirical approach suggested by Deaton and Paxton (1992), Attanasio (1998) and Deaton (1997) could result in the unstable age profiles of financing costs in short panels. They, in turn, focus on analyzing the slope of the age profile of financing costs and control the year effects using a prime lending rate. However, their study does not analyze other aspects of life-cycle effects in small business finance, such as the use of credit, nor does it provide measurements of the magnitude of the age or cohort effects. The current study aims to overcome these shortages by building on the alternative methods suggested in the earlier cohort literature.

\subsection{Estimation of life-cycle profiles}

The empirical analysis of the study proceeds as follows: First, the age profiles of the cost and use of credit are estimated from yearly cross-sections. This method has been a common practice in the previous corporate finance studies that have often used cross-sectional data because of the limitations of the survey datasets (see, e.g., Petersen and Rajan 1994, 1995). This study investigates whether the cross-sectional age profiles are stable over time and whether there are significant biases in the cross-sectional estimates in comparison to the estimates obtained from other methods. This analysis should help to consider the relevance of cross-sectional age profiles in comparison to the profiles obtained from more appropriate cohort methods.

Second, several alternative identification assumptions are considered in the analysis of the life-cycle profiles, building on the earlier suggested cohort methods and full panel dataset. 
Consider a general age, period, and cohort effects model (adopted from Hall et al. 2005) assuming the additively separable nature of the equation defined as follows:

$$
y_{i t}=\underbrace{\mu}_{\text {constant }}+\underbrace{\alpha_{c}}_{\begin{array}{c}
\text { cohort } \\
\text { effects }
\end{array}}+\underbrace{\beta_{t}}_{\begin{array}{c}
\text { time } \\
\text { effects }
\end{array}}+\underbrace{\gamma_{a}}_{\begin{array}{c}
\gamma_{a g e} \\
\text { effects }
\end{array}}+\underbrace{X_{i t}^{\prime} \delta}_{\text {controls }}+\underbrace{\varepsilon_{i t}}_{\begin{array}{c}
\text { efror } \\
\text { term }
\end{array}}
$$

where $y_{i t}$ measures the cost or use of credit, $\mu$ is a constant, $\alpha_{c}$ is the cohort effect, $\beta_{t}$ is the period effect, $\gamma_{a}$ is the age effect, $X_{i t}$ is a vector of control variables, $\varepsilon_{i t}$ is an error term and $i=1, \ldots, N ; c=1, \ldots, C ; \mathrm{t}=1, \ldots, T$ and $a=1, \ldots, A$ index firms, cohorts, time periods, and ages, respectively. The estimation of the above model requires that the indicator variables are estimated relative to their reference values. This is implemented by imposing nullity on the coefficients $\alpha_{1}, \beta_{1}$, and $\gamma_{1}$ that measure the first cohort, period, and age, respectively. This, however, does not remove the collinearity between the age, period, and cohort effects because the variables in the equation are not linearly independent (Hall et al. 2005). Consider the following modifications on equation (1) that allow the identification of the model based on the several alternative identification assumptions:

In the baseline case, the models that contain age dummies (and controls) together with either time or cohort dummies are compared to each other (cf. Heathcote et al. 2005). This comparison provides a useful starting point for the analysis and evaluates the relevance of the time versus cohort effects. These first two models are defined in more detail as follows:

The first model includes time dummies but leaves out all the cohort dummies (i.e., $\alpha_{c}$ is dropped from equation (1)). That is, this model assumes that there are no cohort effects and treats the dataset as a pooled cross-section. The time dummies included in the regressions 
control for the period-specific effects that might arise, e.g., because of macroeconomic or financial factors such as the market level of interest rates or changes in the supply of credit.

The second model includes cohort dummies but no time dummies (i.e., $\beta_{t}$ is dropped from equation (1)). This model accounts for the possibility of the existence of cohort effects but assumes away any time effects, in contrast to the earlier model. The comparison between these first two models provides an informal evaluation about whether the time or cohort dimension is a more important factor influencing the age profiles of the cost and use of credit. However, these baseline models could as such provide an unsatisfactory solution to the identification problem of the age, period, and cohort effects; that is, failure to control one of these distinct dimensions (period or cohort) could result in spurious findings (Mason et al. 1973). Because of this, the baseline models are compared to other models that aim to identify age, period, and cohort effects in several alternative ways.

In the third model, the identification is achieved by aggregating the cohorts into groups by grouping the cohorts at the four-year/level. The grouping of single-year cohorts in this way overcomes the fundamental identification problem (see, e.g., Hall et al. 2005; Levin and Stephan 1991). Hall et al. (2005) note that the grouping of cohorts is equivalent to obtaining the identification of the age effect by comparing closely adjacent ages to each other and assuming that they come from the same cohort. They note, however, that the grouping of cohorts at multi-year intervals may be a less satisfactory solution than utilizing a priori information about the cohorts or time periods in the identification of the models, as suggested by Rodgers (1982). In the current study, special attention is paid to make sure that the cohort groups are natural and match some key macroeconomic and financial regimes observed, for instance, during the Finnish Great Depression and the banking crisis of the 1990s. 
In the fourth model, the time effects are controlled by replacing the time dummies $\beta_{t}$ with macroeconomic control variables following the suggestion of Rodgers (1982) (see also Hall et al. 2005; Gourinchas and Parker 2002). Specifically, Rodgers (1982) advocates the inclusion of such measures correlated with the time effects instead of time dummies to circumvent the identification problem. The macroeconomic controls used here include the aggregate country-level unemployment rates, the house prices growth, the spread in the yields of the ten- and five-year Finnish government bonds, the consumer prices index growth and the GDP growth. These variables should capture some key measures of the macroeconomic conditions that are relevant from the point of view of the financial conditions of the firms.

In the fifth model, the identification is obtained by constraining two time dummy coefficients equal to each other. This approach builds on the suggestion of Mason et al. (1973), who note that it is possible to identify the three sets of dummy variables for age, period, and cohort by setting two coefficients equal to each other in the same dimension (see also Hall et al. 2005). In the current study, this approach is implemented by dropping both the first and last time dummies from the model (i.e., setting both $\beta_{1}$ and $\beta_{T}$ to zero in equation (1)). This allows for the inclusion of the single-year cohort dummies into the model. Recall that the first cohort dummy is dropped from the model to avoid the dummy variable trap because of the constant term.

In the sixth model, the cohort effects $\alpha_{c}$ are replaced with firm fixed effects $\mu_{i}$ in equation (1). The identification is obtained by setting two time dummies equal to each other. As was done earlier, the first and last time dummies are dropped from the model, which 
allows the identification of the model. ${ }^{14}$ In each specification, the standard errors of the panel data models are adjusted for the firm-level clustering. The cross-sectional regressions based on yearly cross-sections use heteroskedasticity robust standard errors.

\section{Life-cycle profiles of financing costs}

\subsection{Cross-sectional analysis}

The regression results for the life-cycle profiles of financing costs estimated from yearly cross-sections are provided in table 2 . The firm age is modeled using a third-order polynomial. The coefficient of age is positive and significant in each yearly cross-section, with the exception of years 2012 and $2013 .{ }^{15}$ The coefficients of age squared and age cubed are negative and positive, respectively, and highly signifícant in most cases. These results indicate a non-linear relationship between the firm ange and the financing costs. The fitted age profiles based on these models are shown in figure 1 . The findings suggest that the life-cycle profiles obtained from the cross-sectional data are hump-shaped. That is, the financing costs of young and old firms are on average lower than those of intermediate age (approximately 10 years). The profiles are relatively similar in different years, although casual examination

14 The consideration of alternative restrictions suggests that the results remain somewhat sensitive to

the choice of the identification assumption. The robustness tests analyzed two alternative

assumptions, which dropped consecutive time dummies either from the start or from the end of the sample. The shapes of the profiles remained relatively similar, whereas the confidence intervals widened from both ends. The identification approach used in the paper aims to take into account the unbalanced nature of the data by dropping the time dummies from both ends of the sample. 
would suggest that the profiles are somewhat flatter in the years when the monetary policy rates are exceptionally high or low. In particular, years 2012 and 2013 show flat profiles, whereas the higher interest rate periods of 2000-2001 or 2008 also show flatter or less accurate profiles.

Table 2 Cross-sectional life-cycle profiles of financing costs

Panel A: Years 2000-2006

\begin{tabular}{|c|c|c|c|c|c|c|c|}
\hline & (1) & (2) & (3) & (4) & (5) & (6) & (7) \\
\hline Year & 2000 & 2001 & 2002 & 2003 & 2004 & 2005 & 2006 \\
\hline $\begin{array}{l}\text { Dependent } \\
\text { variable }\end{array}$ & $\begin{array}{l}\text { Financing } \\
\text { costs }\end{array}$ & $\begin{array}{l}\text { Financing } \\
\text { costs }\end{array}$ & $\begin{array}{l}\text { Financing } \\
\text { costs }\end{array}$ & $\begin{array}{l}\text { Financing } \\
\text { costs }\end{array}$ & $\begin{array}{l}\text { Financing } \\
\text { costs }\end{array}$ & $\begin{array}{l}\text { Financing } \\
\text { costs }\end{array}$ & $\begin{array}{l}\text { Financing } \\
\text { costs }\end{array}$ \\
\hline \multirow[t]{2}{*}{ Age } & $0.0009^{* * *}$ & $0.0007^{* * * *}$ & $0.0009^{* * *}$ & $0.0009^{* * * *}$ & $0.0012^{* * * *}$ & $0.0013^{* * *}$ & $0.0012^{* * * *}$ \\
\hline & $(0.0003)$ & $(0.0003)$ & $(0.0002)$ & $(0.0002)$ & $(0.0002)$ & $(0.0002)$ & $(0.0002)$ \\
\hline \multirow[t]{2}{*}{$\mathrm{Age}^{\wedge} 2$} & $-0.0063^{\text {**** }}$ & $-0.0053^{\text {**** }}$ & $-0.0065^{* * * *}$ & $-0.0066^{* *}$ & $-0.0082^{* * *}$ & $-0.0080^{* * * *}$ & $-0.0075^{* * * *}$ \\
\hline & $(0.0020)$ & $(0.0016)$ & $(0.0013)$ & $(0.0013)$ & $(0.0013)$ & $(0.0014)$ & $(0.0013)$ \\
\hline \multirow[t]{2}{*}{$\mathrm{Age}^{\wedge} 3$} & $0.0011^{* * * *}$ & $0.0009^{* * * * *}$ & $0.0011^{* * * *}$ & $0.0011^{* * *}$ & $0.0013^{* * * *}$ & $0.0013^{* * *}$ & $0.0012^{* * * *}$ \\
\hline & $(0.0004)$ & $(0.0003)$ & $(0.0002)$ & $(0.0002)$ & $(0.0002)$ & $(0.0003)$ & $(0.0002)$ \\
\hline \multirow[t]{2}{*}{$\ln$ (Sales) } & 0.0003 & $0.0009^{* * * *}$ & $0.0007^{* * * *}$ & $0.0005^{\text {***** }}$ & $-0.0013^{* * *}$ & $-0.0013^{* * * *}$ & $-0.0011^{* * * *}$ \\
\hline & $(0.0002)$ & $(0.0002)$ & $(0.0002)$ & $(0.0001)$ & $(0.0002)$ & $(0.0002)$ & $(0.0002)$ \\
\hline \multirow[t]{2}{*}{ Tangibility } & $0.0050^{* * * *}$ & $0.0080^{* * * *}$ & $0.0047^{* * * *}$ & 0.0008 & $-0.0080^{* * * *}$ & $-0.0074^{* * * *}$ & $-0.0064^{* * *}$ \\
\hline & $(0.0014)$ & $(0.0011)$ & $(0.0008)$ & $(0.0008)$ & $(0.0008)$ & $(0.0009)$ & $(0.0009)$ \\
\hline \multirow[t]{2}{*}{ Profitability } & $-0.0074^{* * * *}$ & $-0.0081^{* * * *}$ & $-0.0037^{* * *}$ & $-0.0037^{* * * *}$ & 0.0001 & 0.0008 & -0.0013 \\
\hline & $(0.0017)$ & $(0.0013)$ & & $(0.0009)$ & $(0.0010)$ & $(0.0011)$ & $(0.0011)$ \\
\hline \multirow[t]{2}{*}{ Credit score } & $0.0301^{* * * *}$ & $0.0284^{* * * *}$ & $0.0281^{* * * *}$ & $0.0312^{* * * *}$ & $0.0292^{* * * *}$ & $0.0278^{* * * *}$ & $0.0254^{* * * *}$ \\
\hline & $(0.0020)$ & $(0.0015)$ & $(00012)$ & $(0.0012)$ & $(0.0012)$ & $(0.0013)$ & $(0.0013)$ \\
\hline Industry FE & YES & & YES & YES & YES & YES & YES \\
\hline Region FE & YES & YES & YES & YES & YES & YES & YES \\
\hline$N$ & 14214 & 21906 & 34683 & 35432 & 30889 & 24828 & 26362 \\
\hline $\mathrm{r} 2$ & 0.0499 & 0.0457 & 0.0354 & 0.0421 & 0.0537 & 0.0535 & 0.0409 \\
\hline
\end{tabular}

Panel B: Years 2007-2013

\begin{tabular}{|c|c|c|c|c|c|c|c|}
\hline \multirow{4}{*}{$\begin{array}{l}\text { Year } \\
\text { Dependent } \\
\text { variable }\end{array}$} & \multirow{4}{*}{$\begin{array}{l}2007 \\
\text { Financing } \\
\text { costs }\end{array}$} & (2) & \multirow{4}{*}{$\begin{array}{l}(3) \\
2009 \\
\text { Financing } \\
\text { costs }\end{array}$} & \multirow{4}{*}{$\begin{array}{l}(4) \\
2010 \\
\text { Financing } \\
\text { costs }\end{array}$} & \multirow{4}{*}{$\begin{array}{l}(5) \\
2011 \\
\text { Financing } \\
\text { costs }\end{array}$} & \multirow{4}{*}{$\begin{array}{l}(6) \\
2012 \\
\text { Financing } \\
\text { costs }\end{array}$} & \multirow{4}{*}{$\begin{array}{l}(7) \\
2013 \\
\text { Financing } \\
\text { costs }\end{array}$} \\
\hline & & 2008 & & & & & \\
\hline & & Financing & & & & & \\
\hline & & costs & & & & & \\
\hline Age & $0.0011^{* * * *}$ & $0.0008^{* * * *}$ & $0.0012^{* * * *}$ & $0.0010^{* * * *}$ & $0.0006^{* * * *}$ & 0.0001 & -0.00004 \\
\hline \multirow{3}{*}{$\operatorname{Age}^{\wedge} 2^{a}$} & $(0.0002)$ & $(0.0002)$ & $(0.0002)$ & $(0.0002)$ & $(0.0002)$ & $(0.0002)$ & $(0.0002)$ \\
\hline & $-0.0065^{* * *}$ & $-0.0039^{* *}$ & $-0.0070^{* * * *}$ & $-0.0058^{* * * *}$ & $-0.0036^{* * *}$ & -0.0009 & -0.0001 \\
\hline & $(0.0014)$ & $(0.0016)$ & $(0.0014)$ & $(0.0012)$ & $(0.0012)$ & $(0.0012)$ & $(0.0012)$ \\
\hline \multirow[t]{2}{*}{$\operatorname{Age}^{\wedge} 3^{b}$} & $0.0010^{* * * *}$ & $0.0006^{*}$ & $0.0011^{* * * *}$ & $0.0009^{* * * *}$ & $0.0005^{* *}$ & 0.0001 & -0.00002 \\
\hline & $(0.0003)$ & $(0.0003)$ & $(0.0003)$ & $(0.0002)$ & $(0.0002)$ & $(0.0002)$ & $(0.0002)$ \\
\hline \multirow[t]{2}{*}{$\ln$ (Sales) } & $-0.0007^{* * * *}$ & -0.0000 & $-0.0009^{* * * *}$ & $-0.0012^{* * * *}$ & $-0.0011^{\text {***** }}$ & $-0.0010^{* * * *}$ & $-0.0007^{* * *}$ \\
\hline & $(0.0002)$ & $(0.0002)$ & $(0.0002)$ & $(0.0001)$ & $(0.0001)$ & $(0.0001)$ & $(0.0001)$ \\
\hline \multirow[t]{2}{*}{ Tangibility } & $-0.0031^{* * * *}$ & -0.0015 & $-0.0080^{* * * *}$ & $-0.0091^{* * * *}$ & $-0.0105^{* * *}$ & $-0.0126^{* * * *}$ & $-0.0161^{* * * *}$ \\
\hline & $(0.0009)$ & (0.0009) & $(0.0008)$ & $(0.0007)$ & $(0.0007)$ & $(0.0007)$ & $(0.0007)$ \\
\hline \multirow[t]{2}{*}{ Profitability } & -0.0015 & -0.0010 & 0.0009 & $0.0026^{* * * *}$ & $0.0051^{* * * *}$ & $0.0062^{* * * *}$ & $0.0052^{* * * *}$ \\
\hline & $(0.0012)$ & $(0.0012)$ & $(0.0011)$ & $(0.0009)$ & $(0.0008)$ & $(0.0009)$ & $(0.0009)$ \\
\hline Credit score & $0.0274^{* * * *}$ & $0.0299^{* * * *}$ & $0.0293^{\text {**** }}$ & $0.0272^{* * * *}$ & $0.0239^{* * * *}$ & $0.0303^{* * *}$ & $0.0294^{* * *}$ \\
\hline
\end{tabular}




\begin{tabular}{llllllll} 
& $(0.0014)$ & $(0.0015)$ & $(0.0014)$ & $(0.0011)$ & $(0.0010)$ & $(0.0011)$ & $(0.0010)$ \\
Industry FE & YES & YES & YES & YES & YES & YES & YES \\
Region FE & YES & YES & YES & YES & YES & YES & YES \\
\hline$N$ & 26741 & 26051 & 29914 & 40874 & 42680 & 40885 & 40231 \\
$\mathrm{r} 2$ & 0.0379 & 0.0364 & 0.0491 & 0.0608 & 0.0533 & 0.0650 & 0.0704 \\
\hline
\end{tabular}

The table shows the estimates for the financing costs obtained from the separate yearly cross-sections from the 1999-2013 period. The dependent variable Financing costs is financial expenses divided by the average interest-bearing debt between t-1 and t. The independent variables are defined as follows: Age, modeled as a third-order polynomial, is the age of the firm defined as the years since the initial incorporation at t. $\operatorname{Ln}($ Sales $)$ is a natural logarithm of net sales at t-1. Tangibility is a ratio of fixed to total assets at t-1. Profitability is EBITDA divided by total assets at t-1. Credit score measures the observed creditworthiness of the firms (i.e., the probability of default) at the scale 3-100 (scaled by dividing by 100), where higher values mean lower creditworthiness. The models also include industry dummies measured at the two-digit level, regional dummies measured at the two-digit zip-code level, and a constant. $N$ is the number of observations. $R 2$ stands for R-squared. Heteroskedasticity robust standard errors are in parentheses: $* p<0.10, * * p<0.05$, *** $p<0.01$. (a), (b) The coefficients and standard errors of $a g e^{\wedge} 2$ and $a g e^{\wedge} 3$ have been multiplied by 100 and 1000, respectively.

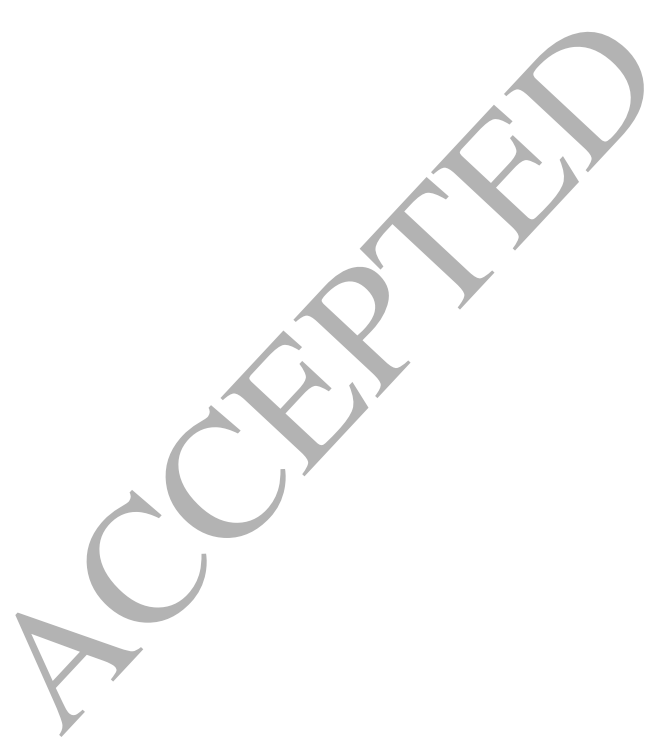



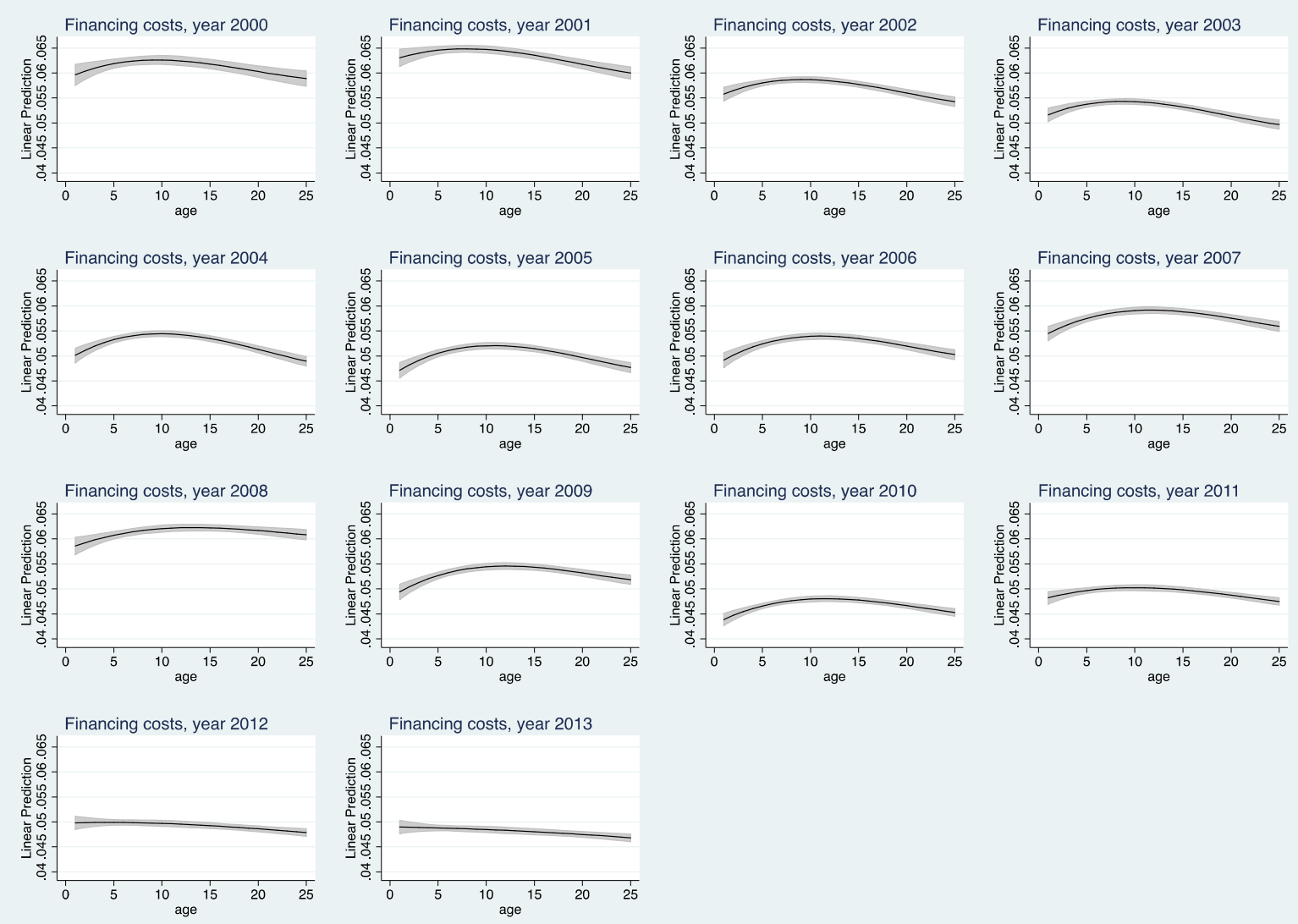

Figure 1 Cross-sectional life-cycle profiles of financing costs

The figures show the fitted life-cycle profiles of financing costs and associated 95\% confidence intervals estimated from the yearly cross-

sections of the 1999-2013 period. The models include a third-order polynomial of firm age and the following controls: $\ln ($ Sales), Tangibility,

Profitability, Credit score, two-digit industry dummies and two-digit zip-code-level regional dummies.

\subsection{Cohort analyses}

The summary of the models that analyze the life-cycle profiles of financing costs using the full dataset and alternative identification assumptions is provided in table 3. Firm age is modeled using dummies for each age in each specification. Note that the time fixed effects and macro controls absorb the overall level of market interest rates. The fitted age profiles obtained from the models are presented in figure 2. The pooled panel model (model 1) that 
controls the time fixed effects provides a hump-shaped age profile, which is very similar to the ones observed in the cross-sectional data. Model 2 replaces the time fixed effects with cohort fixed effects, which results in a downward-sloping age profile. Both models 1 and 2 overcome the fundamental identification problem by assuming away one of the dimensions, i.e., time or cohort effects. However, this assumption could result in biased findings if the ignored distinct dimension remains important for the age profiles.

The next models address the identification problem in the following alternative ways: Model 3 includes time dummies together with aggregated cohort dummies, where the birth years are grouped at the four-year level. This model provides somewhat imprecise results in comparison to other cohort models; the findings based on the grouped cohorts suggest a more hump-shaped age profile than with the single-year cohort dummies. Hence, the aggregation of the cohort groups does not seem to provide a particularly accurate way to control for the cohort effects. Model 4 includes single-year cohort dummies and replaces the time dummies with macroeconomic controls, which results in a downward-sloping age profile of financing costs. This relationship is somewhat more pronounced than in model 2, which lacked the period-specific controls. Model 5 includes both time and cohort dummies and obtains the identification by dropping both the first and last of the time dummies. This results in a downward-sloping age profile of financing costs. Finally, model 6 replaces the cohort fixed effects with firm fixed effects. The identification is obtained by dropping both the first and last time dummies. This model provides a somewhat steeper but otherwise similar age profile as the previous model with cohort dummies. ${ }^{16}$

16 Note that the industry and region dummies are dropped from the fixed effects model given the limited time variation of these variables. 
The control variable estimates seem sensible and provide statistically highly significant findings in most cases. Larger firms pay lower financing costs. Profitability, however, shows positive and negative relationship with financing costs in specifications (1)-(5) and (6), respectively. Firms with more tangible assets in their balance sheet face lower financing costs. Firms with lower credit quality, as indicated by their credit scores, pay more for their credit.

Table 3 Life-cycle profiles of financing costs: model summary

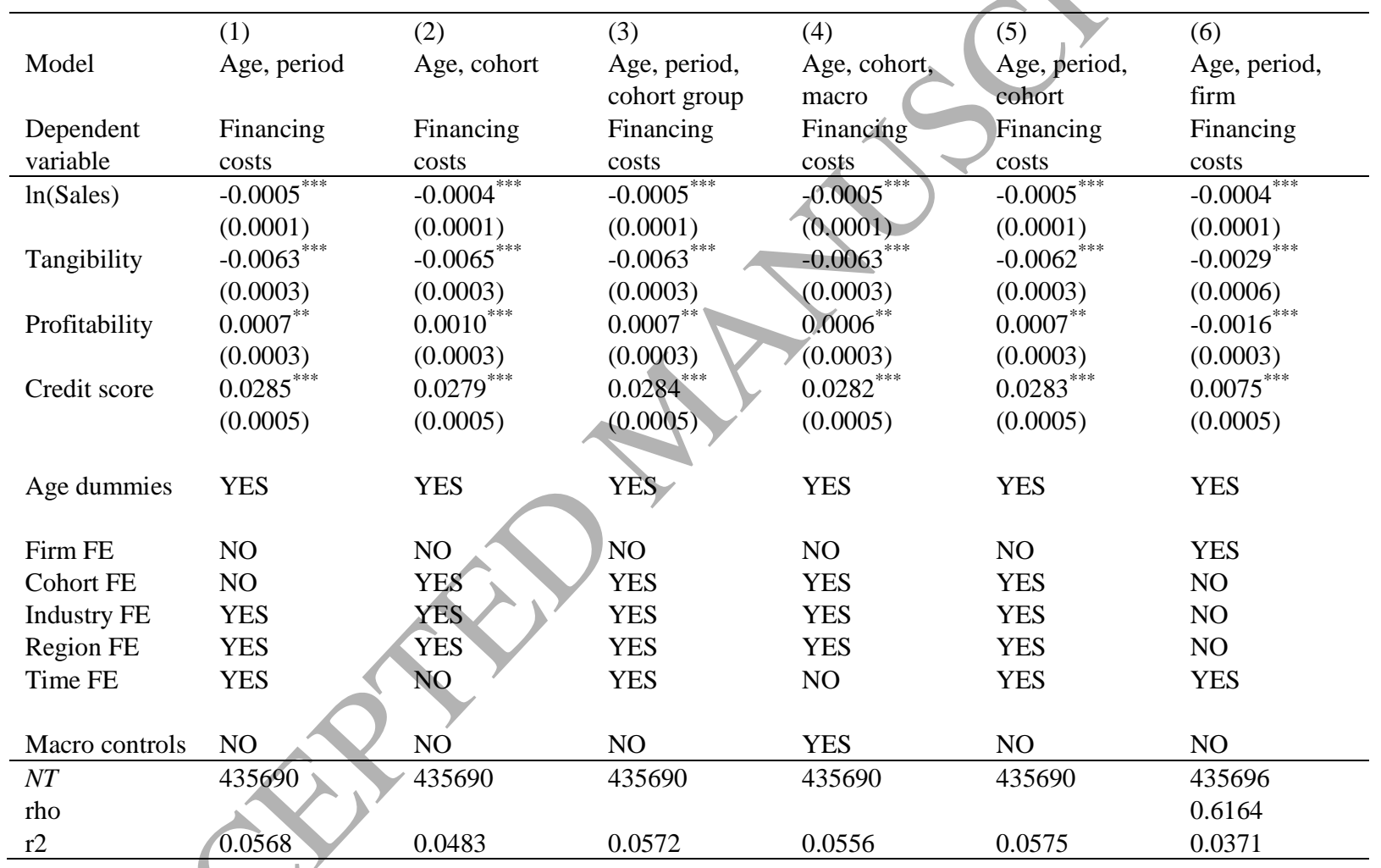

The table shows the estimates for the financing costs obtained from the panel regressions over the 1999-2013 period. The dependent variable Financing costs is financial expenses divided by the average interest-bearing debt between $\mathrm{t}$ and $\mathrm{t}-1$. The independent variables are defined as follows: Age, modeled using dummies for each age, is the age of the firm defined as the years since the initial incorporation at t. $\operatorname{Ln}(\operatorname{Sales})$ is a natural logarithm of net sales at t-1. Tangibility is a ratio of fixed to total assets at t-1. Profitability is EBITDA divided by total assets at t-1. Credit score measures the observed creditworthiness of the firms (i.e., the probability of default) at the scale 3-100 (scaled by dividing by 100), where higher values mean lower creditworthiness. All the models include a constant. The table also reports whether the firm, cohort, 
industry, region, and time fixed effects, and macro controls, are included in the models. NT is the number of firm-year observations. Rho measures the intra-class error correlation. $R 2$ stands for R-squared. Standard errors clustered at the firm level are reported in parentheses: $* p$ $<0.10, * * p<0.05, * * * p<0.01$.
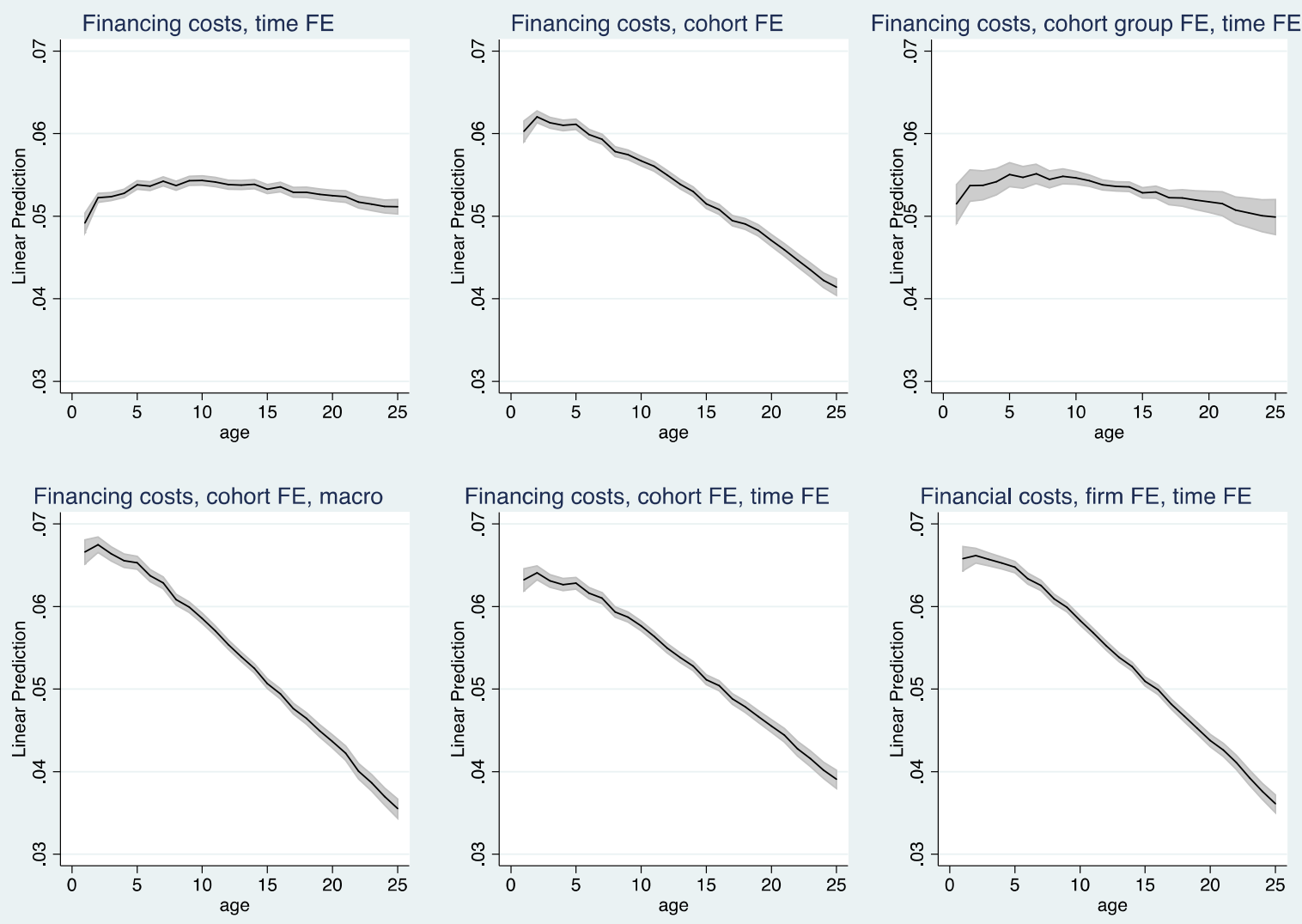

Figure 2 Life-cycle profiles of financing costs

The figures show the fitted life-cycle profiles of financing costs and associated $95 \%$ confidence intervals from the panel regressions over the 1999-2013 period. The models include firm age dummies and the following controls: $\ln ($ Sales), Tangibility, Profitability and Credit score.

In addition, two-digit-level industry dummies and two-digit zip-code-level regional dummies are included in specifications 1-5. The models with the following additional controls are estimated: 1) time fixed effects 2) cohort fixed effects 3 ) cohort fixed effects (birth years grouped at the four-year level) and time fixed effects 4) cohort fixed effects and macro controls 5) cohort and time fixed effects 6) firm and time fixed effects. 
The study considers a number of robustness tests (available on request): First, figure A1 in the appendix shows the age profiles for the 2005-2013 period for which the data on defaults and bankruptcies are available. This analysis considers whether the downward-sloping profile of financing costs could be related to selections effects (e.g., badly performing firms dropping from the sample) even though the creditworthiness of the firms is already controlled with commercial credit scores. To address this issue, the number of missed debt payments and the indicator for bankruptcy applications are included as additional controls. The life-cycle profiles remain similar to the baseline results, while models 5 and 6 show flatter or even a bit hump-shaped profiles for the young firms. However, dropping the survival-related variables suggests that these differences seem to be driven by the sample period rather than the survival-related additional controls. ${ }^{17}$ Second, the analysís is repeated for the balanced panel of firms that survived the 2005-2013 period to study whether the results remain similar in a

Another issue worth considering is whether the hump-shaped profile of financing costs could be related to the possibility that young firms may not be able to secure loans at all and those that do may be of exceptional quality. The following factors should diminish this concern: First, all the sample firms analyzed here have positive financial expenses at $t$ and a positive average amount of interest-bearing debt during $\mathrm{t}$ and $\mathrm{t}-1$. Second, there are thousands (or tens of thousands) of observations in each age group of firms younger than five years in the full sample, indicating that the number of young firms obtaining interest-bearing debt is not trivial. Third, including an indicator for the availability of audited financial statements as an additional control provides virtually identical financing cost profiles. Finally, the credit score already controls the observed creditworthiness of firms. 
consistent sample of firms where the composition of cohort groups does not change. ${ }^{18}$ The life-cycle profiles indeed show similarities with the earlier results, while the profiles are flatter or somewhat hump-shaped for the young firms. However, the data requirements (i.e., nine years of existence) restrict the number of young firms lower than previously and make the estimates less precise. ${ }^{19}$ Overall, controlling for the defaults and bankruptcies and restricting the panel to the surviving firms provides quite similar age profiles as the baseline results. On the other hand, there are some signs of hump-shaped or flatter profiles, suggesting that the study period and sample composition also have a role in the shape of the life-cycle profiles. To further inspect the issue, the models for the 2005-2013 period are reestimated using the CEO age, gender and birth cohort as additional controls beside the survival-related measures. The profiles steepen somewhat and become less accurate but retain similarities with the baseline findings.

The financing cost estimates suggest several key implications: First, the life-cycle profiles of financing costs obtained from the cross-sectional models are in line with the predictions of hold-up theories (e.g., Sharpe 1990, Rajan 1992, von Thadden 2004, and Kim

The survival-related control variables are retained among controls because a bankruptcy application or missed payments do not necessarily results in the (immediate) disappearance of firm from the data; the bankruptcy process could take some time and might not result in a bankruptcy in the end. Finally, while this surviving firm sample is indeed a balanced panel for the bank debt sample, there can be holes in the time series for the financing cost sample because firms may have zero or missing financing costs for some periods (e.g., they could have refrained from using interest-bearing debt). compared to the about $22 \%$ observed in the unbalanced samples 1999-2013 and 2005-2013, respectively. 
et al. 2012). ${ }^{20}$ That is, new firms face lower financing costs, which then rise in the following periods until the firm age of these firms reaches approximately ten years. After that, the financing costs begin to decrease. These findings would be consistent with the situation in which banks compete for new customers, who then become locked in after accepting the loan contract. Over time, the informational asymmetry would start to diminish once the firms reach the intermediate age and would become more transparent. Second, the models that control for cohort or firm fixed effects and use the full sample suggest, in contrast, that the financing costs decrease approximately monotonically when the firms mature. This downward-sloping age profile of financing costs is in line with the prediction of Diamond (1989). Taken together, the findings suggest that the alternative methods in disentangling age, period, and cohort effects provide conflicting implications about the relationship between

The two-period hold-up models of Sharpe (1990), Rajan (1992) and von Thadden (2004) focus on banks' private information and do not concentrate explicitly on firm age. Ioannidou and Ongena (2010) also suggest that the hold-up problem could arise each time after the firms switch banks. However, concentration on the firm age rather than other proxies of banks' private information (for example, relationship length) should make little difference in the current context. First, firm age is a well-reasoned proxy for asymmetric information (see, e.g., Hyytinen and Pajarinen 2008). Second,

even an assumption that the firms would on average borrow only from one bank does not seem unreasonable. Niskanen and Niskanen (2000) utilize cross-sectional Finnish survey data and provide evidence that the average number of firms' banking relationships (including non-borrowers) is 0.85 . The recent survey results support the view that the majority of the firms have few, and in many cases one, bank relationships. Almost $80 \%$ of the micro firms and about $50 \%$ of the small firms that responded to the survey have only one main lending bank (Business Financing Survey 2012). 
firm age and financing costs. ${ }^{21}$ Finally, while the baseline results are perhaps more supportive of the predictions of Diamond (1989) compared to the hold-up theories, the findings from the more recent subsamples are not quite as clear-cut in distinguishing between the theories. ${ }^{22}$

The comparison between the age profiles obtained from the cross-sectional models and the models that control for cohort or firm fixed effects suggests that the differences between the profiles are related to cohort effects. The following analysis examines the cohort effects in more detail. The fitted cohort-specific financing costs evaluated at the cohort years between 1970 and 2011 are shown in figure 3. This figure shows the mean predicted financing costs for a four-year-old firm born during the period 1970-2011 and based on the 2009 economic environment as captured by time dummies. ${ }^{23}$ The findings suggest that the financing costs have a rather smooth downward-sloping profile in terms of cohort year,

The differences between the predictions from the alternative models are not economically trivial. The spread between the financing costs of one- and ten-year-old firms is about -0.5 and 0.8 percentage points in models (1) and (4), respectively. The mean interest-bearing debt of about 385000 euros suggests that one-year-old firms pay about 2000 euros lower and 3000 euros higher financing costs per annum than ten-year-old in models (1) and (4), respectively. The Finnish bahking sector is highly concentrated having three major banking groups. Both the reputational and hold-up theories could provide reasonable descriptions of the markets. The models that control for the cohort or firm fixed effects, which are essential in capturing the unobserved firm heterogeneity, point more in favor of reputational theories, even if the recent sample periods suggest a less clear-cut distinction. It remains an issue worth considering whether changes in the banking environment in more recent periods could explain some differences related to the sample periods. macro controls instead of time dummies, provide similarly shaped profiles. 
despite some bumps observed, for instance, in 2009. That is, holding other things constant, the younger cohorts face lower financing costs than the older cohorts. For instance, the predictions suggest that two identical four-year-old firms born in 1975 and 2005 would face financing costs of approximately $8.6 \%$ p.a. and $5.3 \%$ p.a., respectively, in this economic environment. This is a sizable difference in the cost of credit between the different cohort groups.

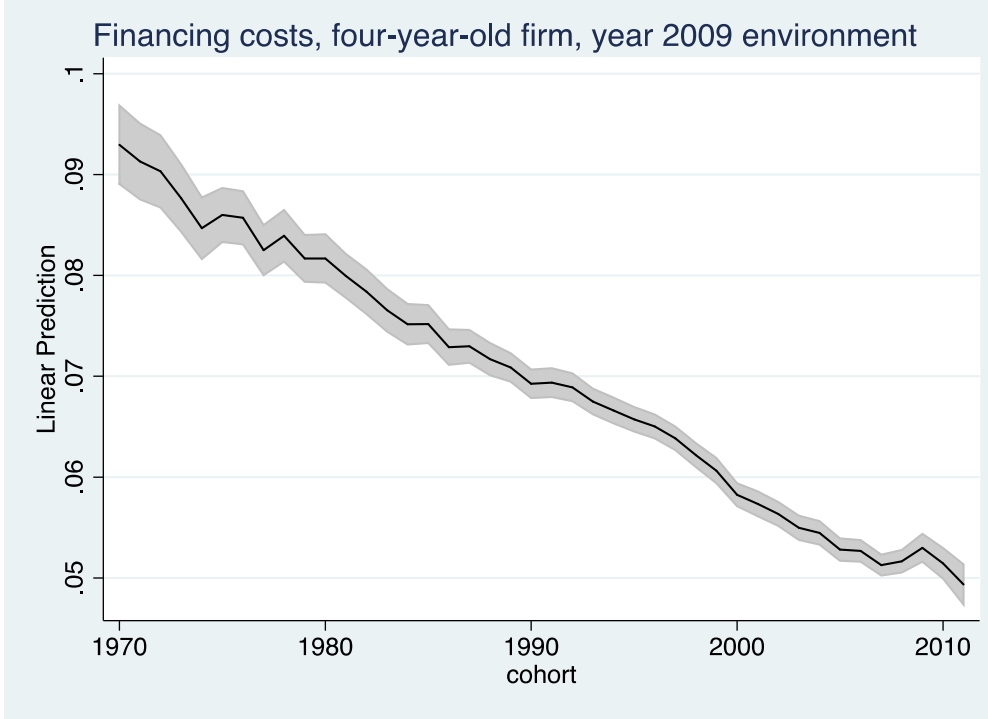

Figure 3 Cohort profile of financing costs

The figure shows the predicted financing costs and associated $95 \%$ confidence intervals for a four-year-old firm evaluated at the cohort years from 1970 to 2011 and year 2009 economic environment. The estimates are based on the panel regressions over the 1999-2013 period. The model includes firm age dummies, single-year cohort dummies and the following controls: In(Sales), Tangibility, Profitability, Credit score, two-digit-level industry dummies, two-digit zip-code-level regional dummies and time dummies.

While this analysis does not formally analyze the source of these cohort effects, the previous literature suggests some potential explanations for the findings. The earlier international literature, including a study by Jappelli and Pagano (2000), suggests that the availability of 
borrower-specific credit information has improved over time because of the birth of credit bureaus and credit rating agencies. Such an improved information environment could generally reduce the adverse selection, lower the informational rents banks can extract from borrowers, and improve borrower discipline (Jappelli and Pagano 1993, 2000; Padilla and Pagano 1997, 2000). Moreover, in the U.S. context, Petersen and Rajan (2002) suggest that in the banking sector, technological innovations, such as credit scoring, have improved the availability of credit for more distant firms. In general, the financial development would reduce the cost of the external finance available to firms (Rajan and Zingales 1998). These predictions from the previous literature appear to be consistent with the observed trend of decreasing cohort-specific financing costs. ${ }^{24}$

\section{Life-cycle profiles of bank financing}

\subsection{Cross-sectional analysis}

The cross-sectional estimates of the life-cycle profiles of bank debt, scaled by total assets, are provided in table 4 . The coefficient of age is negative and statistically highly significant, with the exception of 2000 and 2001, where the coefficient is weakly significant and insignificant, respectively. The coefficients of age squared and age cubed are positive and negative, respectively. The nonlinear terms are also significant, with few exceptions. The fitted lifecycle profiles obtained from the cross-sectional models are shown in figure 4 . The findings

While some financial environment -related factors could be interpreted as time effects, others could show themselves as cohort effects, say, in the form of sticky old credit terms (e.g., higher interest rates). 
indicate that the age profiles of bank debt are s-shaped in the earlier periods, and the downward-sloping relationship is more pronounced in the later years.

Table 4 Cross-sectional life-cycle profiles of bank debt

Panel A: Years 2000-2006

\begin{tabular}{|c|c|c|c|c|c|c|c|}
\hline & (1) & (2) & (3) & (4) & (5) & (6) & (7) \\
\hline Year & 2000 & 2001 & 2002 & 2003 & 2004 & & 2006 \\
\hline $\begin{array}{l}\text { Dependent } \\
\text { variable }\end{array}$ & Bank debt & Bank debt & Bank debt & Bank debt & Bank debt & Bank debt & Bank debt \\
\hline \multirow[t]{2}{*}{ Age } & $-0.0024^{*}$ & -0.0006 & $-0.0029^{* * * *}$ & $-0.0038^{* * * *}$ & $-0.0039^{* * *}$ & $-0.0042^{* * * *}$ & $-0.0041^{* * * *}$ \\
\hline & $(0.0013)$ & $(0.0011)$ & $(0.0009)$ & (0.0009) & $(0.0009)$ & (0.0010) & (0.0009) \\
\hline \multirow[t]{2}{*}{$\operatorname{Age}^{\wedge} 2^{a}$} & $0.0184^{* * *}$ & 0.0097 & $0.0192^{* * * *}$ & $0.0219^{* * * *}$ & $0.0223^{* * * *}$ & $0.0241^{* * * *}$ & $0.0204^{* * *}$ \\
\hline & $(0.0083)$ & $(0.0068)$ & $(0.0055)$ & $(0.0055)$ & $(0.0055)$ & $(0.0059)$ & $(0.0058)$ \\
\hline \multirow[t]{2}{*}{$\mathrm{Age}^{\wedge} 3^{\mathrm{b}}$} & $-0.0038^{* * * *}$ & $-0.0024^{* * *}$ & $-0.0037^{* * *}$ & $-0.0039^{\text {**** }}$ & $-0.0039^{* * * *}$ & $-0.0044^{* * * *}$ & $-0.0034^{* * * *}$ \\
\hline & $(0.0015)$ & $(0.0012)$ & $(0.0010)$ & $(0.0010)$ & $(0.0010)$ & $(0.0011)$ & $(0.0010)$ \\
\hline \multirow[t]{2}{*}{$\ln$ (Sales) } & $0.0040^{* * * *}$ & $0.0063^{* * * *}$ & $0.0085^{* * *}$ & $0.0088^{* * * *}$ & $0.0096^{* * * * *}$ & $0.0104^{* * * *}$ & $0.0113^{* * * *}$ \\
\hline & (0.0009) & (0.0007) & $(0.0006)$ & $(0.0006)$ & $(0.0005)$ & $(0.0006)$ & $(0.0006)$ \\
\hline \multirow[t]{2}{*}{ Tangibility } & $0.2505^{\text {***** }}$ & $0.2445^{* * * *}$ & $0.2260^{* * * *}$ & $0.2245^{* * * *}$ & $0.2345^{* * * *}$ & $0.2496^{* * * *}$ & $0.2436^{* * * *}$ \\
\hline & $(0.0075)$ & $(0.0059)$ & $(0.0045)$ & $(0.0044)$ & $(0.0044)$ & $(0.0049)$ & $(0.0048)$ \\
\hline \multirow[t]{2}{*}{ Profitability } & $-0.0855^{\text {**** }}$ & $-0.0794^{* * * *}$ & $-0.0571^{* * * *}$ & $-0.0601^{* * * * *}$ & $-0.0642^{* * *}$ & $-0.0706^{* * * *}$ & $-0.0659^{* * * *}$ \\
\hline & $(0.0059)$ & $(0.0047)$ & $(0.0034)$ & $(0.0034)$ & $(0.0034)$ & $(0.0037)$ & $(0.0037)$ \\
\hline \multirow[t]{2}{*}{ Credit score } & $0.1783^{* * * *}$ & $0.2188^{* * * *}$ & $0.2226^{* * * *}$ & $0.2183^{* * * *}$ & $0.2079^{* * * *}$ & $0.2075^{* * * *}$ & $0.2384^{* * * *}$ \\
\hline & $(0.0087)$ & $(0.0068)$ & $(0.0055)$ & $(0.0055)$ & $(0.0053)$ & $(0.0058)$ & $(0.0058)$ \\
\hline Industry FE & YES & YES & YES & YES & YES & YES & YES \\
\hline Region FE & YES & YES & YES & YES & YES & YES & YES \\
\hline$N$ & 19379 & 30161 & 48662 & 51756 & 52982 & 43285 & 46117 \\
\hline $\mathrm{r} 2$ & 0.1968 & 0.2078 & 0.1928 & 0.1903 & 0.1899 & 0.2023 & 0.2039 \\
\hline
\end{tabular}

Panel B: Years 2007-2013

\begin{tabular}{|c|c|c|c|c|c|c|c|}
\hline & (1) & (2) & (3) & (4) & (5) & (6) & (7) \\
\hline Year & 2007 & 2008 & 2009 & 2010 & 2011 & 2012 & 2013 \\
\hline $\begin{array}{l}\text { Dependent } \\
\text { variable }\end{array}$ & Bank & Bank debt & Bank debt & Bank debt & Bank debt & Bank debt & Bank debt \\
\hline \multirow[t]{2}{*}{ Age } & $-0.0073^{* x}$ & $-0.0074^{* * *}$ & $-0.0089^{* * *}$ & $-0.0076^{* * *}$ & $-0.0046^{* * *}$ & $-0.0047^{* * *}$ & $-0.0042^{* * *}$ \\
\hline & & $(0.0011)$ & $(0.0010)$ & $(0.0008)$ & $(0.0008)$ & $(0.0008)$ & (0.0008) \\
\hline \multirow[t]{2}{*}{$\operatorname{Age}^{\wedge} 2^{a}$} & $0.0368^{* * *}$ & $0.0356^{* * *}$ & $0.0409^{* * *}$ & $0.0322^{* * *}$ & $0.0164^{* * *}$ & $0.0165^{* * *}$ & $0.0136^{* * *}$ \\
\hline & $(0.0058)$ & (0.0063) & $(0.0061)$ & $(0.0050)$ & (0.0048) & $(0.0048)$ & $(0.0047)$ \\
\hline \multirow[t]{2}{*}{$\operatorname{Age}^{\wedge} 3^{b}$} & $-0.0060^{* * * *}$ & $-0.0055^{* * *}$ & $-0.0060^{* * *}$ & $-0.0046^{* * *}$ & $-0.0020^{* *}$ & $-0.0019^{* *}$ & $-0.0015^{*}$ \\
\hline & $(0.0010)$ & $(0.0011)$ & $(0.0011)$ & (0.0009) & $(0.0008)$ & $(0.0008)$ & $(0.0008)$ \\
\hline \multirow[t]{2}{*}{$\ln$ (Sales) } & $0.0114^{* * * *}$ & $0.0141^{* * * *}$ & $0.0158^{* * *}$ & $0.0161^{* * *}$ & $0.0158^{* * *}$ & $0.0155^{* * *}$ & $0.0165^{* * * *}$ \\
\hline & $(0.0006)$ & $(0.0006)$ & $(0.0006)$ & $(0.0005)$ & $(0.0005)$ & $(0.0005)$ & $(0.0004)$ \\
\hline \multirow[t]{2}{*}{ Tangibility } & $0.2597^{* * * *}$ & $0.2664^{* * * *}$ & $0.2683^{* * *}$ & $0.2414^{* * * *}$ & $0.2419^{* * *}$ & $0.2438^{* * *}$ & $0.2481^{* * * *}$ \\
\hline & $(0.0050)$ & $(0.0051)$ & $(0.0046)$ & $(0.0038)$ & $(0.0037)$ & $(0.0038)$ & (0.0038) \\
\hline \multirow[t]{2}{*}{ Profitability } & $-0.0767^{* * * *}$ & $-0.0772^{* * *}$ & $-0.0834^{* * *}$ & $-0.0528^{* * *}$ & $-0.0488^{* * * *}$ & $-0.0527^{* * * *}$ & $-0.0411^{* * * *}$ \\
\hline & (0.0039) & $(0.0041)$ & $(0.0038)$ & $(0.0028)$ & $(0.0028)$ & $(0.0028)$ & $(0.0026)$ \\
\hline \multirow[t]{2}{*}{ Credit score } & $0.2058^{* * *}$ & $0.2213^{* * *}$ & $0.2329^{* * *}$ & $0.2233^{* * *}$ & $0.2198^{* * *}$ & $0.2082^{* * *}$ & $0.2073^{* * *}$ \\
\hline & $(0.0057)$ & $(0.0066)$ & $(0.0063)$ & $(0.0048)$ & $(0.0046)$ & $(0.0047)$ & $(0.0043)$ \\
\hline Industry FE & YES & YES & YES & YES & YES & YES & YES \\
\hline Region FE & YES & YES & YES & YES & YES & YES & YES \\
\hline$N$ & 45826 & 44435 & 53083 & 76584 & 79833 & 76645 & 77551 \\
\hline
\end{tabular}


The table shows the estimates for the bank debt obtained from the separate yearly cross-sections from the 1999-2013 period. The dependent variable Bank debt is a ratio of outstanding loans from financial institutions divided by total assets at t. The independent variables are defined as follows: Age, modeled as a third-order polynomial, is the age of the firm defined as the years since the initial incorporation at t. $\mathrm{Ln}($ Sales $)$ is a natural logarithm of net sales at t-1. Tangibility is a ratio of fixed to total assets at t-1. Profitability is EBITDA divided by total assets at t-1. Credit score measures the observed creditworthiness of the firms (i.e., the probability of default) at the scale $3-100$ (scaled by dividing by 100), where higher values mean lower creditworthiness. The models also include industry dummies measured at the two-digit level, regional dummies measured at the two-digit zip-code level, and a constant. $N$ is the number of observations. $R 2$ stands for R-squared. Heteroskedasticity robust standard errors are in parentheses: $* p<0.10, * * p<0.05, * * * p<0.01$. (a), (b) The coefficients and standard errors of $a g e^{\wedge} 2$ and $a g e^{\wedge} 3$ have been multiplied by 100 and 1000 , respectively.
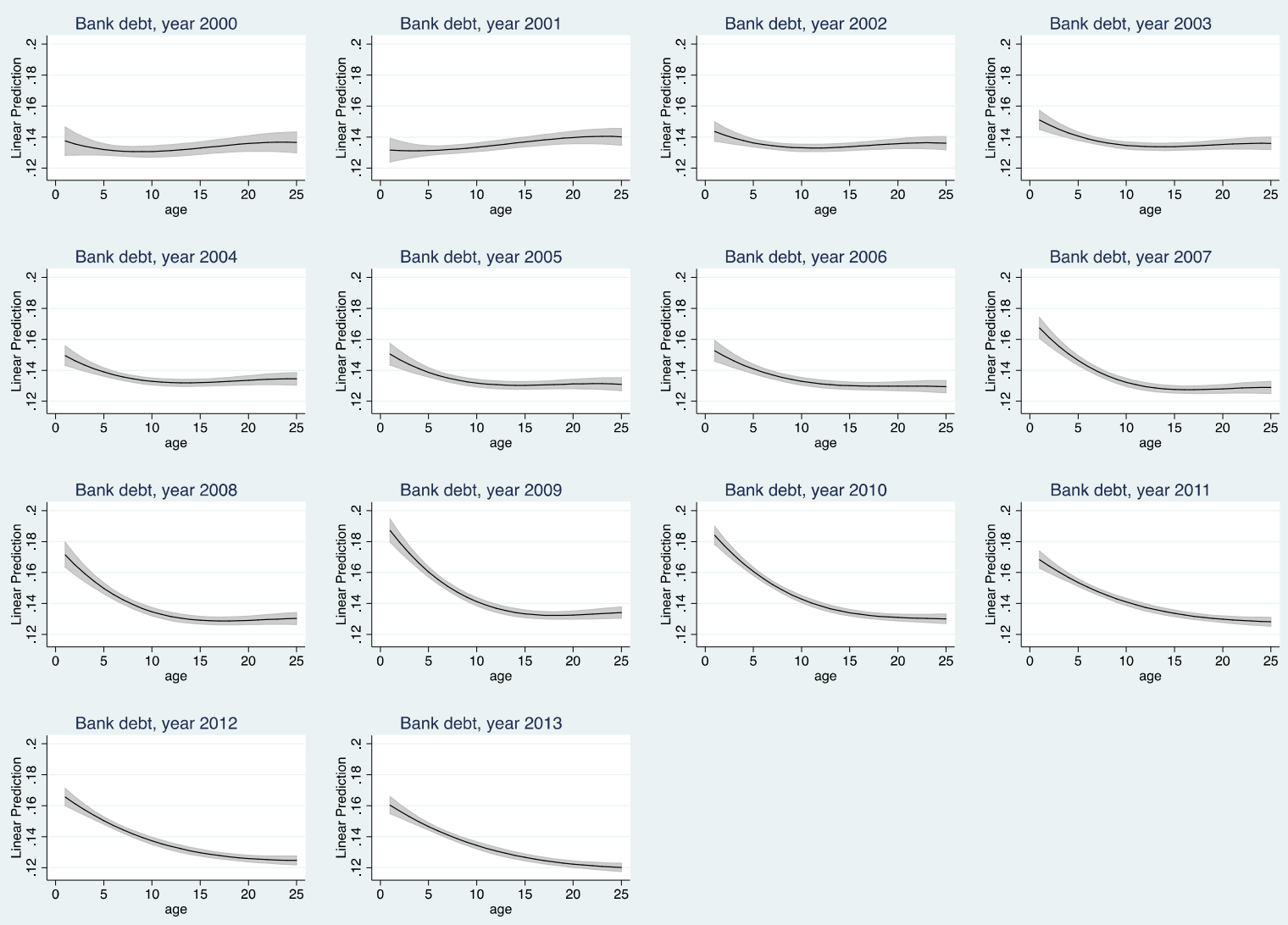
Figure 4 Cross-sectional life-cycle profiles of bank debt

The figures show the fitted life-cycle profiles of bank debt and associated $95 \%$ confidence intervals estimated from the yearly cross-sections of the 1999-2013 period. The models include a third-order polynomial of firm age and the following controls: In(Sales), Tangibility,

Profitability, Credit score, two-digit industry dummies and two-digit zip-code-level regional dummies.

\subsection{Cohort analyses}

The summary of the models for bank debt used based on the full dataset and alternative identification assumptions is provided in table 5. The fitted life-cycle profiles obtained from these models are shown in figure 5. The findings suggest that the age profiles of bank debt are generally downward sloping. The pooled panel model (model 1) and the models with the single-year cohort fixed effects (models 2, 4, 5) provide, rather similar profiles. Model 3, which uses the cohort fixed effects based on the grouped cohorts, provides somewhat imprecise results. The downward-sloping age profile becomes steeper when the firm fixed effects are controlled for (model 6). The findings suggest that firms are more dependent on bank financing in the earlier periods of their lives.

The control variable estimates are in line with the expectations. Larger firms and firms with more tangible assets use more bank debt. More-profitable firms and firms of higher observed creditworthiness use less bank debt. The findings seem consistent with the hypothesis that borrowers with lower credit ratings are more dependent on the monitoring provided by banks, as predicted by Diamond (1991).

Table 5 Life-cycle profiles of bank debt: model summary

\begin{tabular}{lllllll}
\hline Model & $(1)$ & $(2)$ & $(3)$ & $(4)$ & $(5)$ & $(6)$ \\
$\begin{array}{l}\text { Dependent } \\
\text { variable }\end{array}$ & Bge, period & Age, cohort & $\begin{array}{l}\text { Age, period, } \\
\text { cohort group } \\
\text { Bank debt }\end{array}$ & $\begin{array}{l}\text { Age, cohort, } \\
\text { macro } \\
\text { Bank debt }\end{array}$ & $\begin{array}{l}\text { Age, period, } \\
\text { cohort } \\
\text { Bank debt }\end{array}$ & $\begin{array}{l}\text { Age, period, } \\
\text { firm }\end{array}$ \\
\hline $\begin{array}{lllll}\text { Bank debt } \\
\ln (\text { Sales })\end{array}$ & $0.0129^{* * *}$ & $0.0128^{* * *}$ & $0.0128^{* * * *}$ & $0.0128^{* * *}$ & $0.0128^{* * *}$ & $0.0099^{* * * *}$
\end{tabular}




\begin{tabular}{|c|c|c|c|c|c|c|}
\hline \multirow{3}{*}{ Tangibility } & $(0.0003)$ & $(0.0003)$ & $(0.0003)$ & $(0.0003)$ & $(0.0003)$ & $(0.0005)$ \\
\hline & $0.2458^{* * * *}$ & $0.2458^{* * * *}$ & $0.2459^{* * * *}$ & $0.2458^{* * * *}$ & $0.2457^{* * * *}$ & $0.1263^{* * * *}$ \\
\hline & $(0.0023)$ & $(0.0023)$ & $(0.0023)$ & $(0.0023)$ & $(0.0023)$ & $(0.0028)$ \\
\hline \multirow[t]{2}{*}{ Profitability } & $-0.0596^{* * *}$ & $-0.0595^{* * *}$ & $-0.0597^{* * * *}$ & $-0.0597^{* * *}$ & $-0.0596^{* * * *}$ & $-0.0459^{* * *}$ \\
\hline & $(0.0011)$ & $(0.0011)$ & $(0.0011)$ & $(0.0011)$ & $(0.0011)$ & $(0.0010)$ \\
\hline \multirow[t]{2}{*}{ Credit score } & $0.2145^{* * * *}$ & $0.2138^{* * * *}$ & $0.2144^{* * * *}$ & $0.2141^{* * * *}$ & $0.2144^{* * * *}$ & $0.0618^{* * * *}$ \\
\hline & $(0.0024)$ & $(0.0024)$ & $(0.0024)$ & $(0.0024)$ & $(0.0024)$ & $(0.0021)$ \\
\hline Age dummies & YES & YES & YES & YES & YES & YES \\
\hline Firm FE & NO & NO & NO & $\mathrm{NO}$ & $\mathrm{NO}$ & \\
\hline Cohort FE & NO & YES & YES & YES & YES & NO \\
\hline Industry FE & YES & YES & YES & YES & YES & $\mathrm{NO}$ \\
\hline Region FE & YES & YES & YES & YES & & $\mathrm{NO}$ \\
\hline Time FE & YES & NO & YES & NO & & YES \\
\hline Macro controls & NO & $\mathrm{NO}$ & NO & YES & NO & NO \\
\hline$N T$ & 746299 & 746299 & 746299 & 746299 & 746299 & 746309 \\
\hline rho & & & & & & 0.7221 \\
\hline $\mathrm{r} 2$ & 0.1920 & 0.1925 & 0.1924 & 0.1926 & 0.1927 & 0.0286 \\
\hline
\end{tabular}

The table shows the estimates for the bank debt obtained from the panel regressions over the 1999-2013 period. The dependent variable

Bank debt is a ratio of outstanding loans from financial institutions divided by total assets at the independent variables are defined as follows: Age, modeled using dummies for each age, is the age of the firm defined as the years since the initial incorporation at t. $\operatorname{Ln}(\operatorname{Sales})$ is a natural logarithm of net sales at t-1. Tangibility is a ratio of fixed to total assets at t-1. Profitability is EBITDA divided by total assets at t-1. Credit score measures the observed creditworthiness of the firms (i.e., the probability of default) at the scale 3-100 (scaled by dividing by 100), where higher values mean lower creditworthiness. All the models include a constant. The table also reports whether the firm, cohort, industry, region and time fixed effects, and macro controls, are included in the models. $N T$ is the number of firm-year observations. Rho measures the intra-class error correlation. $R 2$ stands for R-squared. Standard errors clustered at the firm level are reported in parentheses: $* p$ $<0.10, * * p<0.05, * * * p<0.01$. 

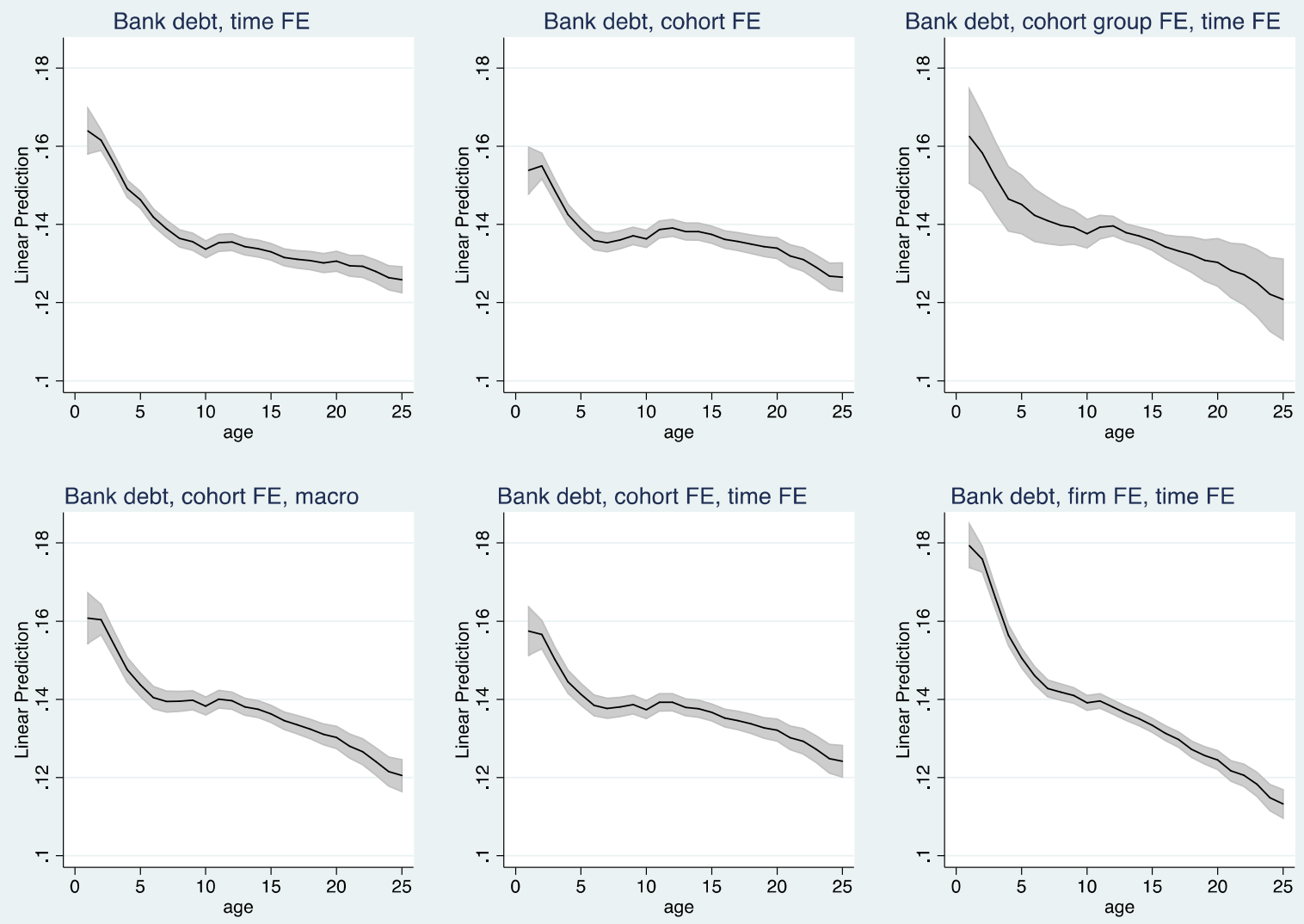

Figure 5 Life-cycle profiles of bank debt

The figures show the fitted life-cycle profiles of bank debt and associated 95\% confidence intervals for the panel regressions over the 1999 -

2013 period. The models include firm age dummies and the following controls: $\ln ($ Sales), Tangibility, Profitability and Credit score. In addition, two-digit-level industry dummies and two-digit zip-code-level regional dummies are included in specifications 1-5. The models with the following additional controls are estimated: 1) time fixed effects 2) cohort fixed effects 3) cohort fixed effects (birth years grouped at the four-year level) and time fixed effects 4) cohort fixed effects and macro controls 5) cohort and time fixed effects 6) firm and time fixed effects.

A number of robustness tests are considered. First, the analysis for the 2005-2013 period using the additional controls for defaults and bankruptcies are shown in figure A2 in the appendix. The life-cycle profiles of bank debt over this sample period are even more 
downward sloping than previously. Second, the balanced panel of surviving firms provides downward-sloping albeit less accurately measured age profiles. Finally, controlling for the age, gender, and cohort of the CEOs besides the survival-related variables results in similarly shaped albeit less accurately measured profiles that vary in the degree of steepness. Overall, the findings on the robustness tests do not change the baseline conclusions.

Figure 6 shows the predicted cohort profile of the amount of bank debt used for a fouryear-old firm born between the periods 1970-2011, and based on the economic environment of year 2009. The findings on this measure suggest that the cohorts born in the 1970s use more bank debt than the cohorts born in the 1980s and in the 1990s. The predicted values are lowest among the cohorts born in the 1990s, which is also the period of the Finnish Great Depression and banking crisis. The figure also indicates that the use of bank debt increases among the cohorts born in the early or mid-2000s and then decreases sharply among the cohorts born closer to the end of the decade. The predicted values of bank debt for two identical four-year-old firms born in 1975 and 2005 are 0.158 and 0.165 , respectively, in the year 2009 economic environment. In comparison, an identical four-year-old firm from the intermediate cohort of 1995 has a predicted value of 0.146 in this environment, which is a lower estimate than obtained for the other two cohorts. The following section complements the analysis by focusing in more detail on the cohorts born during recessions and financial crises. 


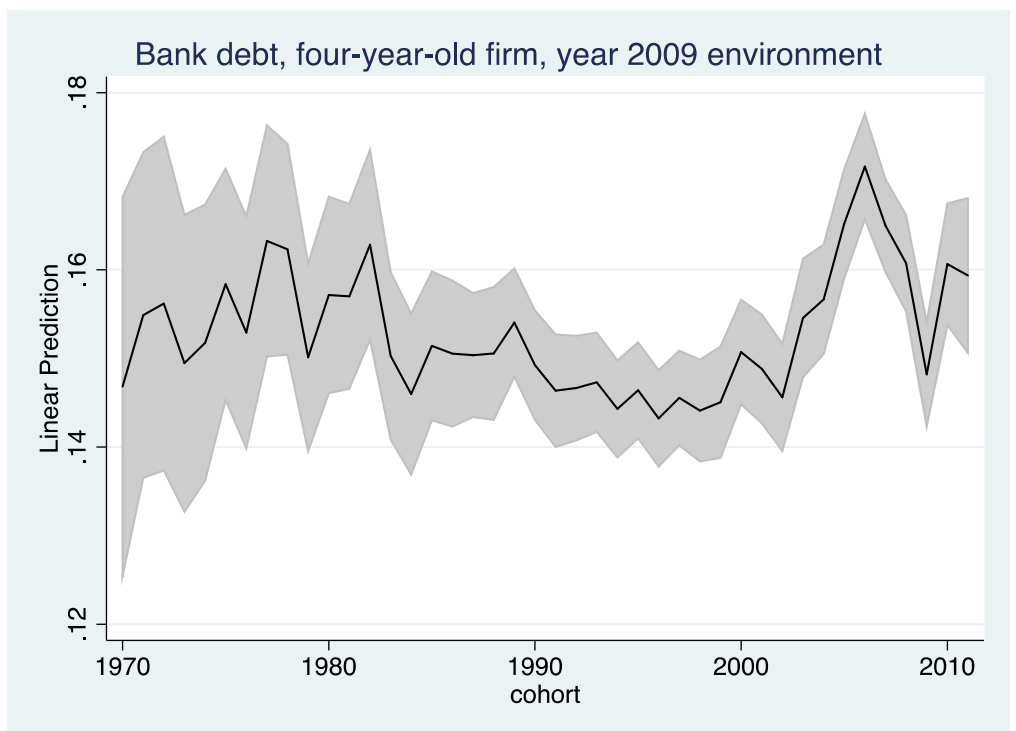

Figure 6 Cohort profile of bank debt

The figure shows the predicted bank debt and associated $95 \%$ confidence intervals for a four-year-old firm evaluated at the cohort years from 1970 to 2011 and year 2009 economic environment. The estimates are based on the panel regressions over the 1999-2013 period. The model includes firm age dummies, single-year cohort dummies and the following controls: In(Sales), Tangibility, Profitability, Credit score, two-digit-level industry dummies, two-digit zip-code-level regional dummies and time dummies.

\section{Recession cohorts}

This section provides a further evaluation of the sources of the cohort effects. The following analysis studies whether the firm cohorts born or the CEO cohorts grown during severe recessions show persistent differences in their costs and use of credit. The focus of the analysis is on the two alternative recession cohort indicators. The first measure is the recession-born dummy, which takes a value equal to one if the firm was born during recession, and zero otherwise. The second measure is the recession-grown CEO dummy, which takes a value equal to one if the CEO experienced a recession during the impressionable years of early adulthood (i.e., between 18 and 25 years). Recessions are 
defined in this context as a year of negative real GDP growth. Based on this definition, the years 1991, 1992, 1993, 2009, and 2012 are defined as recession years. The real GDP contracted during these years by $5.9 \%, 3.3 \%, 0.7 \%, 8.3 \%$ and $1.4 \%$, respectively, according to data from Statistics Finland. These economic contractions reflect two major financial crises that are described in more detail below.

Finland suffered a great depression and banking crisis in the 1990s after the collapse of the Soviet Union - its trade partner - and the boom and bust followed by the liberalization of the Finnish financial markets. The resulting economic contraction in Finland during the period 1991-1993 turned out to be the deepest contraction experienced by an industrialized country since the 1930s (see, e.g., Gorodnichenko et al. 2012). Honkapohja and Koskela (1999) document that trade with the Soviet Union collapsed almost overnight by $70 \%$ in 1991. Their analysis suggests that financial factors were key propagation mechanism for the crisis. After the revaluation of the currency in 1989, Finland had to defend its currency peg from speculative attacks, which kept real interest rates high and short-term rates volatile. The household and firm sectors had become highly indebted because of rapid lending growth in the boom period. Moreover, a large fraction of the corporate borrowing was in foreign currency terms. The hard currency policy was eventually abandoned, which resulted in the depreciation of the Finnish markka in 1991 and 1992 after the forced devaluation and floatation of the currency, respectively. The asset price collapse and the corporate bankruptcies resulted in a banking crisis. Real house prices had risen rapidly in the boom period, only to collapse from the top observed at the end of 1980s to approximately half of their previous value after the financial crisis that accompanied the depression (see, e.g., Honkapohja 2009). 
The Finnish banking sector came close to collapse during the worst years of the depression in 1991-1993, requiring a massive government intervention and restructuring with capital injections and guarantees. The situation stabilized somewhat in 1993, although the banks continued to post losses in 1994 and 1995 despite the improvements in the overall economic situation. The final cost of the banking sector interventions amounted to approximately ten percent of the Finnish annual GDP. (Vihriälä 1997, 37-40.)

More recently, the international financial crisis that followed the collapse of the U.S. investment bank Lehman Brothers caused a large contraction in the Finnish GDP in 2009. The side effects of the crisis were also reflected in the Finnish credit markets, with surveys reporting that approximately 40 percent of micro firms and more than one-fourth of other firms reported financing difficulties - a sharp increase from the previous years (Business Financing Survey 2009). After a rebound, the Finnísh economy slipped back into recession in 2012-2014 because of the weak global anddomestic economy in the post-crisis period. Taken together, these economic contractions and the accompanying financial crises provide an effective testing ground for analyzing the effects of negative shocks faced by the real economy and the banking sector on the firms established during that period.

Because the recession-born dummy is time-invariant, the firm fixed effects must be dropped in the following models. However, the cohort fixed effects based on the aggregated cohorts, in which the single-year cohorts are grouped at the four-year level, are included in the models. This grouping follows the same approach as used in the earlier analysis. In the current analysis, such grouping is implemented to diminish the multicollinearity between the 
cohort and recession-born dummies. ${ }^{25}$ The inclusion of the aggregated cohort dummies is advantageous because they can be used to control for other cohort-specific trends in the cost and use of credit. ${ }^{26}$ Hence, in these cohort models, the recession effects are identified from within the cohort group variation between the firms born in the recession and non-recession years. ${ }^{27}$ Recall that industry, region and time fixed effects are included in each model in addition to the firm characteristics, such as the observed creditworthiness. The further specifications also include the age, gender, and birth cohort of the firm CEOs as controls. ${ }^{28}$

The further specifications also include an interaction between the recession-born firm dummy and the recession-grown CEO dummy to study the role of firm- and CEO-specific

The correlation remains high (that is, close but below 0.80 ) between the recession-born dummy and the cohort group 1990-1993 containing the firms born during the worst depression years of the 1990s. However, the grouping of cohorts at this interval results in natural and balanced cohort groups, which still avoid the perfect multicollinearity while retaining more accuracy than more coarse groupings, such as the decade fixed effects used by Schoar and Zuo (2016). As a reminder, the age profiles based on the grouped cohorts are less precise than the ones based on the individual birth-year dummies as observed in the earlier analysis. In the case of the Finnish Great Depression of the 1990s, the identification comes from the differences between the cohort born in 1990, a year of modest, close-to-zero growth, and the cohorts of 1991-1993, born after the sudden collapse of the Soviet Union and in the middle of the banking crisis. Indeed, comparisons of these particular years are common (cf. Gorodnichenko et al. 2012). Even though the data consist of corporations rather than proprietorships, it is worth noting the following factors: First, the sample firms are mostly very small (median firm size: three persons), suggesting that the firm behavior and personal traits of the CEOs are likely to be more closely linked than among larger firms. Furthermore, the line between personal and corporate assets is more blurred among micro-sized corporations compared to larger, publicly listed firms. 
factors in the recession cohort effects. Furthermore, an interaction between the recession-born dummy and the CEO age analyze whether the effects are different for young and old cohorts.

The previous literature suggests that young individuals could react more strongly to macroeconomic shocks than older ones because the recent experiences constitute a more significant part of their lifetime (see Giuliano and Spilimbergo 2014).

Table 6 Cost and use of credit: cohorts born during recessions

Panel A: Financing costs

\begin{tabular}{|c|c|c|c|c|c|c|}
\hline Dependent variable & $\begin{array}{l}(1) \\
\text { Financing } \\
\text { costs }\end{array}$ & $\begin{array}{l}(2) \\
\text { Financing } \\
\text { costs }\end{array}$ & $\begin{array}{l}(3) \\
\text { Financing } \\
\text { costs }\end{array}$ & $\begin{array}{l}\text { (4) } \\
\text { Financing } \\
\text { costs }\end{array}$ & $\begin{array}{l}(5) \\
\text { Financing } \\
\text { costs }\end{array}$ & $\begin{array}{l}\text { (6) } \\
\text { Financing } \\
\text { costs }\end{array}$ \\
\hline $\ln$ (Sales) & $\begin{array}{l}-0.0005^{* * *} \\
(0.0001)\end{array}$ & $\begin{array}{l}-0.0006^{* * * *} \\
(0.0001)\end{array}$ & $\begin{array}{l}-0.0006^{* * * *} \\
(0.0001)\end{array}$ & $\begin{array}{l}-0.0006^{* * *} \\
(0.0001)\end{array}$ & $\begin{array}{l}-0.0006^{* * * *} \\
(0.0001)\end{array}$ & $\begin{array}{l}-0.0006^{* * * *} \\
(0.0001)\end{array}$ \\
\hline Tangibility & $\begin{array}{l}-0.0063^{* * *} \\
(0.0003)\end{array}$ & $\begin{array}{l}-0.0088^{* * *} \\
(0.0004)\end{array}$ & $\begin{array}{l}-0.0089^{* * * * *} \\
(0.0004)\end{array}$ & $\begin{array}{l}-0.0089^{* * *} \\
(0.0004)\end{array}$ & $\begin{array}{l}-0.0089^{* * *} \\
(0.0004)\end{array}$ & $\begin{array}{l}-0.0088^{* * *} \\
(0.0004)\end{array}$ \\
\hline Profitability & $\begin{array}{l}0.0007^{* * *} \\
(0.0003)\end{array}$ & $\begin{array}{l}0.0008^{* * *} \\
(0.0004)\end{array}$ & $\begin{array}{c}0.0008^{* * *} \\
(0.0004)\end{array}$ & $\begin{array}{l}0.0008^{* * *} \\
(0.0004)\end{array}$ & $\begin{array}{l}0.0008^{* * *} \\
(0.0004)\end{array}$ & $\begin{array}{l}0.0008^{* * *} \\
(0.0004)\end{array}$ \\
\hline Credit score & $\begin{array}{l}0.0284^{* * * *} \\
(0.0005)\end{array}$ & $\begin{array}{l}0.0278^{* * *} \\
(0.0006)\end{array}$ & $\begin{array}{l}0.0278^{* * * *} \\
(0.0006)\end{array}$ & $\begin{array}{l}0.0278^{* * *} \\
(0.0006)\end{array}$ & $\begin{array}{l}0.0278^{* * * *} \\
(0.0006)\end{array}$ & $\begin{array}{l}0.0278^{* * *} \\
(0.0006)\end{array}$ \\
\hline Recession-born & $\begin{array}{l}0.0020^{* * * *} \\
(0.0005)\end{array}$ & $\begin{array}{l}0.0011 \\
(0.0006)\end{array}$ & & $\begin{array}{l}0.0014^{* * *} \\
(0.0006)\end{array}$ & $\begin{array}{l}0.0057 \\
(0.0062)\end{array}$ & $\begin{array}{l}0.0056 \\
(0.0062)\end{array}$ \\
\hline $\ln (\mathrm{CEO}$ age $)$ & & $\begin{array}{l}0.0091 \\
(0.0069)\end{array}$ & $\begin{array}{l}-0.0032^{* * *} \\
(0.0006)\end{array}$ & $\begin{array}{l}-0.0033^{\text {**** }} \\
(0.0006)\end{array}$ & $\begin{array}{l}-0.0028^{* * * *} \\
(0.0006)\end{array}$ & $\begin{array}{l}0.0091 \\
(0.0069)\end{array}$ \\
\hline Female & & $\begin{array}{l}0.0003 \\
(0.0004)\end{array}$ & $\begin{array}{l}0.0003 \\
(0.0004)\end{array}$ & $\begin{array}{l}0.0003 \\
(0.0004)\end{array}$ & $\begin{array}{l}0.0003 \\
(0.0004)\end{array}$ & $\begin{array}{l}0.0003 \\
(0.0004)\end{array}$ \\
\hline $\begin{array}{l}\text { Recession-grown CEO } \\
\text { Recession-grown CEO }\end{array}$ & & & $\begin{array}{l}-0.0003 \\
(0.0003)\end{array}$ & $\begin{array}{l}-0.0002 \\
(0.0003) \\
-0.0010\end{array}$ & & \\
\hline Recession-b & & & & $(0.0008)$ & $\begin{array}{l}-0.0012 \\
(0.0016)\end{array}$ & $\begin{array}{l}-0.0012 \\
(0.0016)\end{array}$ \\
\hline Age dummies & YES & YES & YES & YES & YES & YES \\
\hline Cohort group FE & YES & YES & YES & YES & YES & YES \\
\hline CEO cohort FE & NO & YES & NO & NO & NO & YES \\
\hline Industry FE & YES & YES & YES & YES & YES & YES \\
\hline Region FE & YES & YES & YES & YES & YES & YES \\
\hline Time FE & YES & YES & YES & YES & YES & YES \\
\hline$N T$ & 435690 & 254737 & 254737 & 254737 & 254737 & 254737 \\
\hline $\mathrm{r} 2$ & 0.0573 & 0.0579 & 0.0573 & 0.0573 & 0.0573 & 0.0579 \\
\hline
\end{tabular}

Panel B: Bank debt

\begin{tabular}{lllllll}
\hline & $(1)$ & $(2)$ & $(3)$ & $(4)$ & $(5)$ & $(6)$ \\
Dependent variable & Bank debt & Bank debt & Bank debt & Bank debt & Bank debt & Bank debt \\
\hline $\ln$ (Sales) & $0.0128^{* * * *}$ & $0.0119^{* * * *}$ & $0.0122^{* * *}$ & $0.0122^{* * * *}$ & $0.0122^{* * * *}$ & $0.0119^{* * *}$
\end{tabular}




\begin{tabular}{|c|c|c|c|c|c|c|}
\hline \multirow{3}{*}{ Tangibility } & $(0.0003)$ & $(0.0004)$ & $(0.0004)$ & $(0.0004)$ & $(0.0004)$ & $(0.0004)$ \\
\hline & $0.2458^{* * *}$ & $0.2551^{* * * *}$ & $0.2551^{* * * *}$ & $0.2550^{* * * *}$ & $0.2550^{* * * *}$ & $0.2550^{* * * *}$ \\
\hline & $(0.0023)$ & $(0.0030)$ & $(0.0030)$ & $(0.0030)$ & $(0.0030)$ & $(0.0030)$ \\
\hline \multirow[t]{2}{*}{ Profitability } & $-0.0597^{* * * *}$ & $-0.0645^{* * * *}$ & $-0.0645^{* * *}$ & $-0.0645^{* * * *}$ & $-0.0646^{* * * *}$ & $-0.0645^{* * *}$ \\
\hline & $(0.0011)$ & $(0.0015)$ & $(0.0015)$ & $(0.0015)$ & $(0.0015)$ & $(0.0015)$ \\
\hline \multirow[t]{2}{*}{ Credit score } & $0.2144^{* * *}$ & $0.2398^{* * *}$ & $0.2399^{* * *}$ & $0.2399^{* * * *}$ & $0.2399^{* * *}$ & $0.2398^{* * *}$ \\
\hline & $(0.0024)$ & $(0.0032)$ & $(0.0032)$ & $(0.0032)$ & $(0.0032)$ & $(0.0032)$ \\
\hline \multirow[t]{2}{*}{ Recession-born } & $-0.0088^{* * * *}$ & $-0.0058^{* *}$ & & -0.0044 & $-0.0897^{* * * *}$ & $-0.0971^{* * * *}$ \\
\hline & $(0.0023)$ & $(0.0030)$ & & $(0.0031)$ & $(0.0301)$ & $(0.0301)$ \\
\hline \multirow[t]{2}{*}{$\ln (\mathrm{CEO}$ age $)$} & & $0.1053^{* * *}$ & $-0.0434^{* * *}$ & $-0.0434^{* * *}$ & $-0.0455^{* * *}$ & $0.1069^{* * *}$ \\
\hline & & $(0.0328)$ & $(0.0033)$ & $(0.0033)$ & & $(0.0328)$ \\
\hline \multirow{2}{*}{ Female } & & 0.0012 & 0.0016 & 0.0016 & & 0.0013 \\
\hline & & $(0.0017)$ & $(0.0017)$ & $(0.0017)$ & & $(0.0017)$ \\
\hline \multirow[t]{2}{*}{ Recession-grown CEO } & & & -0.0006 & 0.0001 & & \\
\hline & & & $(0.0017)$ & $(0.0018)$ & & \\
\hline \multicolumn{7}{|l|}{ Recession-grown CEO $\times$} \\
\hline \multicolumn{7}{|l|}{ Recession-born } \\
\hline \multirow[t]{2}{*}{ Recession-born $\times \ln ($ CEO age $)$} & & & & & & $0.0237^{* * *}$ \\
\hline & & & & & $(0.0078)$ & $(0.0078)$ \\
\hline Age dummies & YES & YES & YES & & YES & YES \\
\hline Cohort group FE & YES & YES & YES & YES & YES & YES \\
\hline CEO cohort FE & NO & YES & NO & NO & NO & YES \\
\hline Industry FE & YES & YES & YES & YES & YES & YES \\
\hline Region FE & YES & YES & YES & YES & YES & YES \\
\hline Time FE & YES & YES & YES & YES & YES & YES \\
\hline$N T$ & 746299 & 431666 & 431666 & 431666 & 431666 & 431666 \\
\hline $\mathrm{r} 2$ & 0.1924 & 0.2070 & 0.2063 & 0.2064 & 0.2064 & 0.2071 \\
\hline
\end{tabular}

The table shows the estimates for the financing costs and bank debt from the panel regressions over the 1999-2013 period (column (1)) and

the 2003-2013 period (columns (2)-(6)). The dependent variables are defined as follows: Financing costs is financial expenses divided by

the average interest-bearing debt between $\mathrm{t}$ and $\mathrm{t}-1$. Bank debt is a ratio of outstanding loans from financial institutions divided by total

assets at t. The independent variables are defined as follows: Age, modeled using dummies for each age, is the age of the firm defined as the years since the initial incorporation at t. $\operatorname{Ln}($ Sales $)$ is a natural logarithm of net sales at t-1. Tangibility is a ratio of fixed to total assets at t-1. Profitability is EBITDA divided by total assets at $\mathrm{t}-1$. Credit score measures the observed creditworthiness of the firms (i.e., the probability of default) at the scale 3-100 (scaled by dividing by 100), where higher values mean lower creditworthiness. Recession-born is an indicator equal to one, if the firm was born during the period of negative real GDP growth (years 1991, 1992, 1993, 2009, and 2012), and zero otherwise. $\operatorname{Ln}(\mathrm{CEO}$ age $)$ is a natural logarithm of the age of the CEO. Female is an indicator for female CEOs. Recession-grown CEO is an indicator equal to one if the CEO experienced a recession in the early adulthood (ages between 18 and 25), and zero otherwise. The cohort dummies, where the birth year is grouped at the four-year level, are included in the models. Specifications (2) and (6) also include CEO 
birth cohort dummies. All the models include industry, region and time dummies, and a constant. NT is the number of firm-year observations. $R 2$ stands for R-squared. Standard errors clustered at the firm level are reported in parentheses: * $p<0.10, * * p<0.05$, *** $p$ $<0.01$.

The results are shown in table 6. In the case of financing costs, the recession-born dummy is positive and statistically highly significant in the baseline model. This estimate suggests that the cohorts born during recessions and financial crises pay approximately 20 basis points more for their credit, when the observed creditworthiness of the firms is held constant. ${ }^{29}$ When the entrepreneur-specific controls (i.e., the age, gender, and birth cohort of the CEO) are included in the model, the recession-born dummy is positive but weakly significant. The coefficient is somewhat more conservative, suggesting 11 basis points higher financing costs in this subsample for which the entrepreneur-specific controls are available.

The recession-grown CEO dummy is insignificant in column (3), suggesting that the financing costs are not significantly different for the recession-grown CEOs. Columns (4)-(6) analyze whether the recession-born firm effects are different for recession-grown (or young) CEOs, by including the interactions between the recession-born dummy and the recessiongrown CEO dummy (or the measure of CEO age). The interactions are both insignificant, suggesting that the recession cohort effects on financing costs are limited to the starting period of the firm.

The cohort profiles provided earlier suggest that the recession-born effect on financing costs is most pronounced among the recent financial crisis cohort of 2009, showing an upward bump in financing costs. The slightly different assumptions used in that model might explain the less pronounced recession-born effect for the 1991-1993 cohort compared to the estimates shown above. 
Regarding the use of bank loans, the recession-born dummy is negative and highly statistically significant. That is, the recession-born cohorts use lower amounts of bank loans than the non-recession cohorts. The coefficient remains negative and statistically significant, albeit somewhat more conservative, after the entrepreneur-specific controls are included. ${ }^{30}$ The recession-grown CEO dummy is insignificant, suggesting that the experience of a recession in the yearly adulthood is not significantly reflected in the use of bank loans for these particular cohorts and time periods. Columns (4) shows that the interaction between the recession-born dummy with the recession-grown CEO dummy is negative albeit insignificant, suggesting that the recession-born effects are not significantly larger for firms with CEOs grown during recessions in the full sample. Columns (5)-(6) analyze whether the recession effects are different between old and young CEOs by including the interactions between the recession-born dummy and the age of the CEO. The interactions are positive and highly significant for bank loans, indicating that the recession-born effects on the use of bank loans are larger in absolute terms for the firms with younger CEOs. The average marginal effects for the recession-born dummy from specifications (1) and (3) evaluated at the (log of) CEO ages 25 and 45 are -0.021 and -0.007 , indicating that the recession-born effects are three times as large for the younger CEOs as for the older CEOs.

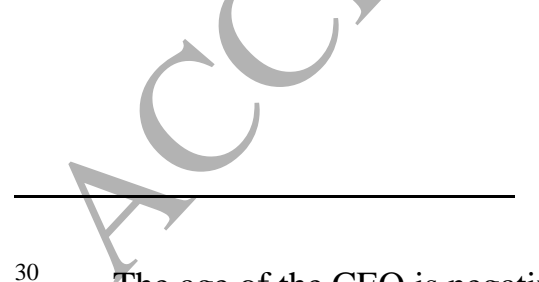

30 The age of the CEO is negatively and significantly related to financing costs albeit this effect is not robust to the inclusion of the CEO birth cohort dummies. On the other hand, the age of the CEO is significantly related to the use of bank loans, whereas the sign of the effect depends on whether the CEO birth cohort dummies are included in the model. Furthermore, the gender of the CEO is not significantly related to either the cost or use of credit. 
Table 7 Cost and use of credit: the Finnish Great Depression cohorts

Panel A: Financing costs

\begin{tabular}{|c|c|c|c|c|c|c|}
\hline Dependent variable & $\begin{array}{l}(1) \\
\text { Financing } \\
\text { costs }\end{array}$ & $\begin{array}{l}(2) \\
\text { Financing } \\
\text { costs }\end{array}$ & $\begin{array}{l}(3) \\
\text { Financing } \\
\text { costs }\end{array}$ & $\begin{array}{l}(4) \\
\text { Financing } \\
\text { costs }\end{array}$ & $\begin{array}{l}(5) \\
\text { Financing } \\
\text { costs }\end{array}$ & $\begin{array}{l}\text { (6) } \\
\text { Financing } \\
\text { costs }\end{array}$ \\
\hline $\ln ($ Sales $)$ & $\begin{array}{l}-0.0002^{* *} \\
(0.0001)\end{array}$ & $\begin{array}{l}-0.0003^{* * *} \\
(0.0001)\end{array}$ & $\begin{array}{l}-0.0003^{* * *} \\
(0.0001)\end{array}$ & $\begin{array}{l}-0.0003^{* * *} \\
(0.0001)\end{array}$ & $\begin{array}{l}-0.0003^{* * *} \\
(0.0001)\end{array}$ & $\begin{array}{l}-0.0003^{* * *} \\
(0.0001)\end{array}$ \\
\hline Tangibility & $\begin{array}{l}-0.0012^{* * *} \\
(0.0004)\end{array}$ & $\begin{array}{l}-0.0049^{* * * *} \\
(0.0006)\end{array}$ & $\begin{array}{l}-0.0049^{* * * *} \\
(0.0006)\end{array}$ & $\begin{array}{l}-0.0048^{* * * *} \\
(0.0006)\end{array}$ & $\begin{array}{l}-0.0049^{* * * *} \\
(0.0006)\end{array}$ & $\begin{array}{l}-0.0049^{* * * *} \\
(0.0006)\end{array}$ \\
\hline Profitability & $\begin{array}{l}-0.0027^{* * *} \\
(0.0004)\end{array}$ & $\begin{array}{l}-0.0028^{* * *} \\
(0.0006)\end{array}$ & $\begin{array}{l}-0.0028^{* * *} \\
(0.0006)\end{array}$ & $\begin{array}{l}-0.0028^{* * *} \\
(0.0006)\end{array}$ & $\begin{array}{l}-0.0028 * * \\
(0.0006)\end{array}$ & $\begin{array}{l}-0.0028^{* * *} \\
(0.0006)\end{array}$ \\
\hline Credit score & $\begin{array}{l}0.0285^{* * *} \\
(0.0006)\end{array}$ & $\begin{array}{l}0.0282^{* * * *} \\
(0.0008)\end{array}$ & $\begin{array}{l}0.0282^{* * * *} \\
(0.0008)\end{array}$ & $\begin{array}{l}0.0282^{* * *} \\
(0.0008)\end{array}$ & $\begin{array}{l}0.0282 * * * \\
(0.0008)\end{array}$ & $\begin{array}{l}0.0282^{* * *} \\
(0.0008)\end{array}$ \\
\hline Recession-born & $\begin{array}{l}0.0018^{* * *} \\
(0.0007)\end{array}$ & $\begin{array}{l}0.0014 \\
(0.0010)\end{array}$ & & $\begin{array}{l}0.0016 \\
(0.0010)\end{array}$ & $\begin{array}{l}0.0034 \\
(0.0093)\end{array}$ & $\begin{array}{l}0.0044 \\
(0.0093)\end{array}$ \\
\hline $\ln (\mathrm{CEO}$ age $)$ & & $\begin{array}{l}-0.0194 \\
(0.0150)\end{array}$ & $\begin{array}{l}-0.0025^{* * *} \\
(0.0009)\end{array}$ & $\begin{array}{l}-0.0025^{* * *} \\
(0.0009)\end{array}$ & $\begin{array}{l}-0.0018^{* *} \\
(0.0008)\end{array}$ & $\begin{array}{l}-0.0192 \\
(0.0150)\end{array}$ \\
\hline Female & & $\begin{array}{l}0.0005 \\
(0.0005)\end{array}$ & $\begin{array}{l}0.0005 \\
(0.0005)\end{array}$ & $\begin{array}{l}0.0005) \\
(0.0005)\end{array}$ & $\begin{array}{l}0.0005 \\
(0.0005)\end{array}$ & $\begin{array}{l}0.0005 \\
(0.0005)\end{array}$ \\
\hline Recession-grown CEO & & & & $\begin{array}{l}-0.0004 \\
(0.0005)\end{array}$ & & \\
\hline $\begin{array}{l}\text { Recession-grown CEO } \times \\
\text { Recession-born }\end{array}$ & & & & -0.0011 & & \\
\hline Recession-born $\times \ln (\mathrm{CEO}$ age $)$ & & & & & $\begin{array}{l}-0.0005 \\
(0.0024)\end{array}$ & $\begin{array}{l}-0.0008 \\
(0.0024)\end{array}$ \\
\hline Age dummies & YES & & YES & YES & YES & YES \\
\hline Cohort group FE & YES & YES & YES & YES & YES & YES \\
\hline CEO cohort FE & NO & YES & NO & NO & NO & YES \\
\hline Industry FE & YES & YES & YES & YES & YES & YES \\
\hline Region FE & YES & YES & YES & YES & YES & YES \\
\hline Time FE & YES & YES & YES & YES & YES & YES \\
\hline$N T$ & 241106 & 115723 & 115723 & 115723 & 115723 & 115723 \\
\hline $\mathrm{r} 2$ & 0.0477 & 0.0524 & 0.0514 & 0.0515 & 0.0514 & 0.0524 \\
\hline
\end{tabular}

Panel B: Bank debt

\begin{tabular}{|c|c|c|c|c|c|c|}
\hline Dependent & $\begin{array}{l}\text { (1) } \\
\text { Bank debt }\end{array}$ & $\begin{array}{l}\text { (2) } \\
\text { Bank debt }\end{array}$ & $\begin{array}{l}\text { (3) } \\
\text { Bank debt }\end{array}$ & $\begin{array}{l}\text { (4) } \\
\text { Bank debt }\end{array}$ & $\begin{array}{l}\text { (5) } \\
\text { Bank debt }\end{array}$ & $\begin{array}{l}(6) \\
\text { Bank debt }\end{array}$ \\
\hline \multirow[t]{2}{*}{$\ln$ (Sales) } & $0.0099^{* * *}$ & $0.0086^{* * *}$ & $0.0089^{* * *}$ & $0.0089^{* * *}$ & $0.0089^{* * *}$ & $0.0086^{* * *}$ \\
\hline & $(0.0004)$ & $(0.0005)$ & $(0.0005)$ & $(0.0005)$ & $(0.0005)$ & $(0.0005)$ \\
\hline \multirow{2}{*}{ Tangibility } & $0.2431^{* * * *}$ & $0.2538^{* * * *}$ & $0.2538^{* * * *}$ & $0.2537^{* * * *}$ & $0.2537^{* * * *}$ & $0.2538^{* * *}$ \\
\hline & $(0.0029)$ & $(0.0040)$ & $(0.0040)$ & $(0.0040)$ & $(0.0040)$ & $(0.0040)$ \\
\hline \multirow[t]{2}{*}{ Profitability } & $-0.0680^{* * * *}$ & $-0.0735^{* * *}$ & $-0.0736^{* * *}$ & $-0.0736^{* * *}$ & $-0.0736^{* * *}$ & $-0.0736^{* * *}$ \\
\hline & $(0.0016)$ & $(0.0023)$ & $(0.0023)$ & $(0.0023)$ & $(0.0023)$ & $(0.0023)$ \\
\hline \multirow[t]{2}{*}{ Credit score } & $0.2152^{* * * *}$ & $0.2351^{* * * *}$ & $0.2353^{* * * *}$ & $0.2352^{* * * *}$ & $0.2353^{* * *}$ & $0.2351^{* * * *}$ \\
\hline & $(0.0031)$ & $(0.0042)$ & $(0.0042)$ & $(0.0042)$ & $(0.0042)$ & $(0.0042)$ \\
\hline \multirow[t]{2}{*}{ Recession-born } & $-0.0088^{* * * *}$ & -0.0046 & & -0.0034 & $-0.0953^{* *}$ & $-0.0900^{* * *}$ \\
\hline & $(0.0033)$ & $(0.0045)$ & & $(0.0046)$ & $(0.0429)$ & $(0.0429)$ \\
\hline \multirow[t]{2}{*}{$\ln (\mathrm{CEO}$ age $)$} & & $0.2914^{* * * *}$ & $-0.0421^{* * * *}$ & $-0.0422^{* * * *}$ & $-0.0414^{* * *}$ & $0.2851^{* * * *}$ \\
\hline & & $(0.0677)$ & $(0.0047)$ & $(0.0047)$ & $(0.0041)$ & $(0.0677)$ \\
\hline \multirow[t]{2}{*}{ Female } & & 0.0024 & 0.0027 & 0.0028 & 0.0028 & 0.0024 \\
\hline & & $(0.0023)$ & $(0.0023)$ & $(0.0023)$ & $(0.0023)$ & $(0.0023)$ \\
\hline Recession-grown CEO & & & -0.0032 & -0.0018 & & \\
\hline
\end{tabular}




\begin{tabular}{|c|c|c|c|c|c|c|}
\hline \multirow{2}{*}{$\begin{array}{l}\text { Recession-grown CEO } \times \\
\text { Recession-born }\end{array}$} & & & \multirow[t]{2}{*}{$(0.0025)$} & \multicolumn{3}{|l|}{$(0.0026)$} \\
\hline & & & & & & \\
\hline Recession-born $\times \ln (\mathrm{CEO}$ age $)$ & & & & $(0.0059)$ & $\begin{array}{l}0.0232^{* *} \\
(0.0110)\end{array}$ & $\begin{array}{l}0.0220^{* *} \\
(0.0110)\end{array}$ \\
\hline Age dummies & YES & YES & YES & YES & YES & YES \\
\hline Cohort group FE & YES & YES & YES & YES & YES & \\
\hline CEO cohort FE & NO & YES & NO & NO & NO & YES \\
\hline Industry FE & YES & YES & YES & YES & YES & YES \\
\hline Region FE & YES & YES & YES & YES & YES & YES \\
\hline Time FE & YES & YES & YES & YES & YES & YES \\
\hline$N T$ & 382603 & 184919 & 184919 & 184919 & & 184919 \\
\hline $\mathrm{r} 2$ & 0.1945 & 0.2117 & 0.2104 & 0.2105 & 0.2104 & 0.2118 \\
\hline
\end{tabular}

The table shows the estimates for the financing costs and bank debt from the panel regressions over the 1999-2008 period (column (1)) and the 2003-2008 period (columns (2)-(6)). Recession-born is an indicator equal to one, if the firm was born during the Finnish Great

Depression (years 1991, 1992, and 1993), and zero otherwise. Recession-grown CEO is an indicator equal to one if the CEO experienced the Finnish Great Depression in the early adulthood (ages between 18 and 25), and zero otherwise. See the previous table for the rest of the definitions. Standard errors clustered at the firm level are reported in parentheses: $* p<0.10, * * p<0.05, * * * p<0.01$.

Table 7 reproduces the baseline results for the 1999-2008 period before the international financial crisis with the recession-born indicator now focusing solely on the cohorts born during the Finnish Great Depression and the accompanying banking crisis of the 1990s. In a similar fashion, the recession-grown CEO indicator focuses on the CEO cohorts who lived through the Finnish Great Depression during the impressionable years of their early adulthood. These cohorts should provide useful information for drawing inference about the long-term effects of severe economic depressions and banking crises. This newly defined recession-born indicator takes a value equal to one if the firm is born during the crisis years 1991, 1992 or 1993, and zero otherwise. This should provide a useful robustness test because the estimates of the younger cohorts observed for a shorter period of time and during the 
financial market turbulence might be less accurate in comparison to their older counterparts. ${ }^{31}$ The concentration on the older cohorts born in the 1990s should provide further insights on whether the recession effects have a lasting rather than transitory impact on the firms.

The results that focus on the depression cohorts of the 1990s in the pre-2008 period remain very similar to the previous estimates as can be seen from specification(1). The additional specifications with the entrepreneur-specific controls also show similar albeit statistically insignificant estimates. The recession-born effect in the financing costs of these cohorts is 18 basis points, in line with the results observed in the case of the more broadly defined recession cohort.

In the case of bank loans, the interaction between the recession-born dummy and the recession-grown CEO dummy is negative and now weakly significant in column (4), suggesting that the recession-born firm effects are larger in absolute term for the CEO cohorts grown during the Finnish Great Depression. The average marginal effects of the recessionborn dummy for the recession-grown CEOs are -0.014 and significant at the 5\% level. The economic magnitude of the effect appears to be significant; the predicted values of the bank debt $(0.124)$ for the recession-grown CEOs in the recession-born firms are more than nine percent lower than for the non-recession-grown CEOs (0.137). The interactions between the recession-born firm dummy and the CEO age remain positive and significant in columns (5)(6). The average marginal effects for the recession-born dummy in column (6) evaluated at 
the (log of) CEO ages 25 and 45 are about -0.019 and -0.006 , respectively. They are significant at the 5\% level for the younger cohort and insignificant for the older cohort.

Overall, these findings suggest that the depression cohorts of the 1990s are a key group behind the persistent differences between the recession and the non-recession cohorts observed previously in the analysis. However, the further (unreported) analysis suggests that the significance of the younger recession cohorts has risen relative to the older depression cohorts during the more recent periods in the aftermath of the international financial crisis. ${ }^{32}$

The magnitude of the recession-born effect on the financing costs (up to 20 basis points) roughly matches and even exceeds the magnitude of a five-point change in the credit score from the lower bound of the credit rating class AA+ (credit score: 20) to the lower bound of the credit rating class AA (credit score: 25 ). This credit rating change would increase the predicted financing costs approximately 14 basis points (i.e., from $4.97 \%$ p.a. to $5.11 \%$ p.a). The persistent recession-born effect of a similar magnitude is intriguing because the observed creditworthiness of the firms is controlled for in the regressions. The recession-born effect on the amount of bank debt used also appears to be significant in economic terms. Because the mean value of bank debt is 0.137 , the baseline recession-born estimate of approximately 0.009 suggests that the recession cohorts use an amount of bank debt that is more than six percent lower than the amount used by the non-recession cohorts. The observation of such a

The baseline estimates for the Finnish Great Depression cohort remain quite robust up to year 2010 .

The statistical significance and size of the estimates for this cohort is weaker and more conservative, respectively, in the sample covering the later years of the post-crisis period. This could indicate that the younger recession cohorts start to dominate in the sample during the more recent years and that ignoring them would underestimate the effect. Indeed, the prolonged Finnish recession that began in 2012 has continued in 2013-2014, already matching the length of the 1990s depression. 
lasting impact suggests persistent differences either in the firms' perceived riskiness or in the entrepreneurs' attitudes towards bank finance. This result suggests that severe recessions and periods of financial instability could have scarring effects.

The previous literature suggests that certification provided by banks is particularly important for firms that do not have access to public debt markets (see, e.g., Diamond 1991; Slovin et al. 1993). This suggests that any problems in the lending relationships could have potentially far-reaching implications for the firms. Indeed, the cohorts born during the Finnish Great Depression in the middle of the banking crisis of the 1990s could have lost their access to intermediated credit. The previous literature indicates that the lost access to financial intermediates and the termination of lending relationships because of the banking crises could be damaging to the firms (e.g., Bernanke 1983; Slovin et al. 1993; Peek and Rosengren 2000; Kroszner et al 2007; Khwaja and Mian 2008). The firms could also have suffered financially because of steep and prolonged economic contraction. The disruptions in lending relationships and otherfinancial problems could explain why the firms might be perceived as of lower quality from the lenders' point of view than otherwise identical firms born during stronger economic times. ${ }^{33}$

Second, the earlier literature suggests that corporate managers who started out during recessions could have less faith in financial markets and could utilize external finance more conservatively (cf. Graham and Narasimhan 2004; Malmendier and Nagel 2011; Malmendier

Alternatively, one could also make an argument that these firms at least survived the depression, unlike other potentially lower quality firms. This potential selection effect is worth entertaining in the interpretation. However, a survivorship bias of this kind could in fact predict an opposite sign for the estimates and suggest even larger absolute effects than observed here. 
et al. 2011; Schoar and Zuo 2016). Malmendier et al. (2011) suggest that recession cohorts, having witnessed a major financial crisis, may be debt averse and lean excessively towards internal finance. Schoar and Zuo (2016) also suggest that recession-born managers make more conservative capital structure choices, including lower use of leverage. Indeed, these differences in the attitude towards bank finance could explain why the recession cohorts use bank loans in smaller amounts than other cohorts.

The findings of this study also indicate that the recession-born effects are largest among the young CEOs, suggesting that the scarring effects are most damaging for them. These findings appear to be in line with the psychological and economic literature that suggests that macroeconomic shocks have a more significant effect on young individuals (see Giuliano and Spilimbergo 2014). However, the recession cohort effect appears to be more related to the firms started during recessions rather than to the earlier experiences of the CEOs grown up in recessions, at least in the sample covering also the recent post-crisis years of the international financial crisis. Meanwhile, the analysis of the Finnish Great Depression cohorts in the pre2008 period suggests that the long-term impact of the recession-born firm effect on the use of bank loans is larger for the recession-grown (and young) CEOs (i.e., those, who were still young adults when their firm was started). Taken together, the findings of the study suggest that the experience of a recession during the (early years of) entrepreneurship appears to be an important factor driving the findings on the long-lasting recession impact. ${ }^{34}$ The previous studies that analyze the cohort-specific effects of the Great Depression and other U.S. recessions have focused on publicly listed firms. The current study suggests that similar 
persistent effects are observed among privately held small businesses in a different institutional environment in Finland.

\section{Conclusions}

This paper studied the life-cycle profiles of small firms' financing costs and the use of bank financing. The study used an extensive panel of Finnish firms from the 1999-2013 period and paid attention to disentangling age, period, and cohort effects in the empirical models. This identification problem has been largely ignored in the earlier corporate finance literature. The findings of the current study suggest that the choice of method affects the conclusions drawn about the relationship between financing costs and firm age. The cross-sectional age profiles of financing costs are hump-shaped and consistent with the hold-up theories. In contrast, the methods that control for cohort or firm fixed effects suggest that the financing costs decrease monotonically as the firms mature, in line with the prediction of Diamond (1989). The findings suggest that these differences in the life-cycle profiles relate to cohort effects. Moreover, the age profiles of the use of credit indicate that firms are more dependent on financial intermediaries in the early periods of their lives.

A few main findings are made about the cohort effects. First, the younger cohorts face lower costs of credit than the older cohorts. While the source of this cohort effect was not formally tested, the longer-term trend of decreasing cohort-specific financing costs would generally appear to be consistent with the hypothesis regarding improvements in the financial system and information environment. Second, the findings suggest that the cohorts born in recessions, particularly the Finnish Great Depression and accompanying banking crisis of the 1990s and the more recent international financial crisis, face higher financing costs and use lower amounts of bank loans in a persistent fashion. This effect is robust to controlling for the 
creditworthiness of the firms with commercial credit scores. The recession-born firm effect is larger for younger CEOs, in line with the prediction that macroeconomic shocks have a more significant effect on young individuals. However, the recession cohort effect appears to be more related to the experience of starting-up the firm in the recession than to the CEOs growing up in a recession during their early adulthood. Overall, these findings suggest that recessions and periods of financial instability could have a lasting impact on the perceived riskiness of the firms and their use of external finance in the future. Such persistent effects, observed even many years after the depression and banking crisis of the 1990s, are intriguing and might call for additional research to further understand their causes.

The findings could also prove useful in the designing of policies to avoid lasting adverse effects from recessions and periods of financial instability. First, the decrease in the cost of credit has diminished the case for government intervention. Second, the life-cycle profiles of the cost and use of credit indicate that potential policy interventions would likely have best rationalization when targeting younger firms. Finally, the long-lasting recession effects faced by the recession cohorts imply that the periods of financial instability might call for some policy measures targeted to bank-dependent small businesses. However, an effective implementation of the policy measures remains a key challenge.

Taken together, the findings of the paper suggest that the choice of method in disentangling age, period, and cohort effects matters for the conclusions drawn about the lifecycle effects in small business finance. One key implication from the analysis is that the lifecycle profiles estimated from cross-sectional datasets, whose use has been a common practice in the previous corporate finance literature, should be interpreted with caution. Moreover, the existence of cohort effects in the cost and use of credit observed in this study also suggests that the identification problem should not be overlooked either in the repeated cross-section 
or in the panel datasets. The future literature could further study the scope of the cohort effects in various institutional environments.

\section{Acknowledgements}

This paper uses the data provided by Suomen Asiakastieto Oy. I would like to thank Etlatieto ltd for providing access to the data. The financial support from the OP Group Research Foundation and the Foundation for Economic Education is gratefully acknowledged.

\section{References}

Attanasio, O.P. 1998. Cohort analysis of saving behavior by U.S. Households. The Journal of Human Resources 33 (3), 575-609.

Beck, T., Demirguc-Kunt, A., Laeven, L., Maksimovic, V. 2006. The determinants of financing obstacles. Journal of International Money and Fiannce 25, 932-952.

Berger, A.N. and Udell, G.F. 1998. The economics of small business finance: The roles of private equity and debt markets in the financial growth cycle. Journal of Banking \& Finance 22, 613-673.

Bernanke, B. 1983. Nonmonetary effects of the financial crisis in the propagation of the great depression. American Economic Review 73 (3), 257-276.

Bernanke, B. and Gertler, M. 1989. Agency costs, net worth, and business fluctuations. The American Economic Review 79 (1), 14-31.

Bernhardsen, E. and Larsen, K. 2003. Banks' pricing of risk associated with corporate lending. Norges Bank, Economic Bulletin 74, 24-34.

Boot, A.W.A. \& Thakor, A.V. 1994. Moral hazard and secured lending in an infinitely repeated credit market game. International Economic Review 35 (4), 899-920. 
Business Financing Survey 2009 (Yritysten rahoituskysely 2009), joint survey of the Bank of Finland, the Ministry of Employment and the Economy, and the Confederation of Finnish Industries. (Available in Finnish)

Business Financing Survey 2012 (Yritysrahoituskysely 2012), joint survey of the Confederation of Finnish Industries, the Federation of Finnish Financial Services, Finnvera plc, the Bank of Finland, the Federation of Finnish Enterprises and the Ministry of Employment and the Economy. (Available in Finnish)

Chava, S. and Purnanandam, A. 2011. The effect of banking crisis on bank-dependent borrowers. Journal of Financial Economics 99, 116-135.

Deaton, A.S. and Paxson, C.H. 1992. Saving, growth, and aging in Taiwan. The studies in the Economics of Aging, 331-362.

Deaton, A. 1997. The analysis of household surveys: A microeconometric approach to development policy. The John Hopkins University Press, Baltimore.

Degryse, H., Kim, M. and Ongena, S. 2009. Microeconometrics of banking: Methods, applications and results. Oxford University Press.

Dell'Ariccia, G., Detragiache, E. and Rajan, R. 2008. The real effect of banking crises. Journal of Financial Intermediation 17, 89-112.

Diamond, D. 1989. Reputation acquisition in debt markets. Journal of Political Economics 97 (4), 828-862.

Diamond, D.W. 1991. Monitoring and reputation: the choice between bank loans and directly placed debt. The Journal of Political Economy 99(4), 689-721.

Freixas, X., Rochet, J.-C. 2008. Microeconomics of Banking. Second edition. The MIT Press. Gertler, M. and Gilchrist, S. 1994. Monetary policy, business cycles, and the behavior of small manufacturing firms. Quarterly Journal of Economics 109 (2), 309-340. 
Giuliano, P. and Spilimbergo, A. 2014. Growing up in a recession. Review of Economic Studies 81, 787-817.

Gorodnichenko, Y., Mendoza, E.G. and Tesar, L.L. 2012. The Finnish great depression: From Russia with love. American Economic Review 102 (4), 1619-1643.

Gourinchas, P.-O. and Parker, J.A. 2002. Consumption over the life cycle. Econometrica 70 (1), 47-89.

Graham, J.R. and Narasimhan. 2004. Corporate survival and managerial experiences during the great depression. Working paper, Duke University and University of Pennsylvania. Hall, B.H., Mairesse, J. and Turner, L. 2005. Identifying age, cohort and period effects in scientific research productivity: Discussion and illustration using simulated and actual data on French physicist. NBER Working Paper Series, Working Paper 11739.

Heathcote, J., Storesletten, K. and Violante, G.L. 2005. Two views of inequality over the life cycle. Journal of the European Economic Association 3 (2/3), 765-775.

Hjerppe, R. 1989. The Finnish economy 1960-1985. Growth and structural change. Bank of Finland Publications, Studies on Finland's Economic Growth XIII. Helsinki: Bank of Finland/Government Printing Centre.

Hjerppe, R. 2010. Suomen talouden kasvun vaihteet ja vaihtelut 1860-2010 (Finland's economic development and its fluctuations, 1860-2010). Academia Scientiarum Fennica 2010, 46-55.

Holmström, B. and Tirole, J. 1997. Financial intermediation, loanable funds, and the real sector. The Quarterly Journal of Economics 112 (3), 663-691.

Honkapohja, S. 2009. The 1990's financial crises in Nordic countries. Bank of Finland Research Discussion Papers 5/2009. 
Honkapohja, S. and Koskela, E. 1999. The economic crisis of the 1990s in Finland. Economic Policy 14 (29), 399-436.

Hyytinen, A. and Väänänen, L. 2006. Where do financial constraints originate from? An empirical analysis of adverse selection and moral hazard in capital markets. Small Business Economics 27, 323-348.

Hyytinen, A. and Pajarinen, M. 2007. Is the cost of debt capital higher for younger firms? Scottish Journal of Political Economy 54 (1), 55-71.

Hyytinen, A. and Pajarinen, M. 2008. Opacity of young businesses: Evidence from rating disagreements. Journal of Banking \& Finance, 32, 1234-1241.

Ioannidou, V. and Ongena, S. 2010. Time for a change: Loan conditions and bank behavior when firms switch banks. The Journal of Finance 65 (5), 1847-1877.

Jappelli, T. and Pagano, M. 1993. Information sharing in credit markets. The Journal of Finance 48 (5), 1693-1718.

Jappelli, T. and Pagano, M. 2000. Information sharing in credit markets: A survey. Centre for Studies in Economics and Finance, Working Paper no. 36.

Kahn, L.B. 2010. The long-term market consequences of graduating from college in a bad economy. Labor economics 17, 303-316.

Kashyap, A.K., Lamont, O.A. and Stein, J.C. 1994. Credit conditions and the cyclical behavior of inventories. The Quarterly Journal of Economics 109 (3), 565-592.

Khwaja, A.I. and Mian, A. 2008. Tracing the impact of bank liquidity shocks: Evidence from an emerging market. American Economic Review 98 (4), 1413-1442.

Kim, M., Kristiansen, E.G. and Vale, B. 2012. Life-cycle patterns of interest-rate mark-ups in small-firm finance. Scandinavian Journal of Economics 114 (2), 629-657. 
Kiyotaki, N. and Moore, J. 1997. Credit cycles. Journal of Political Economy 105 (21), 211248.

Knüpfer, S., Rantapuska, E. and Sarvimäki, M. 2016. Formative experiences and portfolio choice: Evidence from the Finnish Great Depression. Journal of Finance, forthcoming.

Kroszner, R.S., Laeven, L. and Klingebiel, D. 2007. Banking crises, financial dependence, and growth. Journal of Financial Economics 84, 187-228.

Levin, S.G. and Stephan, P.E. 1991. Research productivity over the life cycle: evidence for academic scientists. The American Economic Review 81(1), 114-132.

Malmendier, U. and Nagel, S. 2011. Depression babies: Do macroeconomic experiences affect risk-taking? Quarterly Journal of Economics 126 (1), 373-416.

Malmendier, U., Tate, G. and Yan, J. 2011. Overconfidence and early-life experiences: The effect of managerial traits on corporate financial policies. Journal of Finance 66 (5), $1687-1733$.

Mason K.O., Mason, W.M., Winsborough, H.H. and W.K. Poole. 1973. Some methodological issues in cohort analysis of archival data. American Sociological Review 38 (2), 242-258.

Niskanen, J. and Niskanen, M. 2000. Does relationship banking have value for small firms? The Finnish Journal of Business Economics 2, 245-262.

Oyer, P. 2006. Initial labor market conditions and long-term outcomes for economists. Journal of Economic Perspectives 20 (3), 143-160.

Pagano, M. and Jappelli, T. 1993. Information sharing in credit markets. The Journal of Finance 48 (5), 1693-1718.

Padilla, A.J. and Pagano, M. 1997. Endogenous communication among lenders and entrepreneurial incentives. The Review of Financial Studies 10 (1), 205-236. 
Padilla, A.J. and Pagano, M. 2000. Sharing default information as a borrower discipline device. European Economic Review 44, 1951-1980.

Peek, J. and Rosengren, E.S. 2000. Collateral damage: The effects of the Japanese crisis on real activity in the United States. The American Economic Review 90 (1), 30-45.

Petersen, M.A. and Rajan, R.G. 1994. The benefits of lending relationships: Eyidence from small business data. The Journal of Finance 49 (1), 3-37.

Petersen, M.A. and Rajan, R.G. 1995. The effects of credit market competition on lending relationships. The Quartely Journal of Economics 110 (2), 407-443.

Petersen, M.A. and Rajan, R.G. 2002. Does distance still matter? The information revolution in small business lending. The Journal of Finance 57 (6), 2533-2570.

Rajan, R.G. 1992. Insiders and outsiders: The choice between informed and arm's-length debt. The Journal of finance 47 (4), 1367-1400.

Rajan, R.G. and Zingales, L. 1998. Financial dependence and growth. The American Economic Review 88 (3), 559-586.

Rodgers, W.L. 1982. Estimable functions of age, period and cohort effects. American Sociological Review 47 (6), 774-787.

Sakai, K., Uesugi, I. and Watanabe, T. 2010. Firm age and the evolution of borrowing costs: Evidence from Japanese firms. Journal of Banking and Finance 34, 1970-1981.

Schoar, A. and Zuo, L. 2016. Shaped by booms and busts: How the economy impacts CEO careers and management styles. Review of Financial Studies, forthcoming.

Sharpe, S.A. 1990. Asymmetric information, bank lending, and implicit contracts: A stylized model of customer relationships. The Journal of Finance 45 (4), 1069-1087.

Slovin, M.B., Sushka, M.E. and Polonchek, J.A. 1993. The value of bank durability: Borrowers as bank stakeholders. The Journal of Finance 48 (1), 247-266. 
Vihriälä, V. 1997. Banks and the Finnish credit cycle 1986-1995. Bank of Finland Studies E:7 1997.

von Thadden, E.-L. 2004. Asymmetric information, bank lending and implicit contracts: the winner's curse. Finance Research Letters 1, 11-23.

\section{Appendix}

Table A 1 Panel statistics

\begin{tabular}{|c|c|c|c|c|c|c|c|}
\hline \multicolumn{4}{|c|}{ Panel A: Financing costs sample 2000-2013 } & \multicolumn{4}{|c|}{ Panel B: Bank debt sample 2000-2013 } \\
\hline Year & Freq. & Percent & Cum. & Year & & Percent & Cum. \\
\hline 2000 & 14214 & 3.26 & 3.26 & 2000 & 19379 & 2.6 & 2.6 \\
\hline 2001 & 21906 & 5.03 & 8.29 & 2001 & 30161 & 4.04 & 6.64 \\
\hline 2002 & 34683 & 7.96 & 16.25 & 2002 & 48662 & 6.52 & 13.16 \\
\hline 2003 & 35432 & 8.13 & 24.38 & 2003 & 51756 & 6.94 & 20.09 \\
\hline 2004 & 30889 & 7.09 & 31.47 & 2004 & 52982 & 7.1 & 27.19 \\
\hline 2005 & 24828 & 5.7 & 37.17 & 2005 & 43285 & 5.8 & 32.99 \\
\hline 2006 & 26362 & 6.05 & 43.22 & 2006 & 46117 & 6.18 & 39.17 \\
\hline 2007 & 26741 & 6.14 & & 2007 & 45826 & 6.14 & 45.31 \\
\hline 2008 & 26051 & 5.98 & & 2008 & 44435 & 5.95 & 51.27 \\
\hline 2009 & 29914 & & 62.2 & 2009 & 53083 & 7.11 & 58.38 \\
\hline 2010 & 40874 & & 71.59 & 2010 & 76584 & 10.26 & 68.64 \\
\hline 2011 & 42680 & & 81.38 & 2011 & 79833 & 10.7 & 79.34 \\
\hline 2012 & 40885 & 9.38 & 90.77 & 2012 & 76645 & 10.27 & 89.61 \\
\hline 2013 & & 9,23 & 100 & 2013 & 77551 & 10.39 & 100 \\
\hline Total & 435690 & 100 & & Total & 746299 & 100 & \\
\hline
\end{tabular}

The table reports the panel statistics for each year, including the number of firm observations and the associated percentages of the sample. 

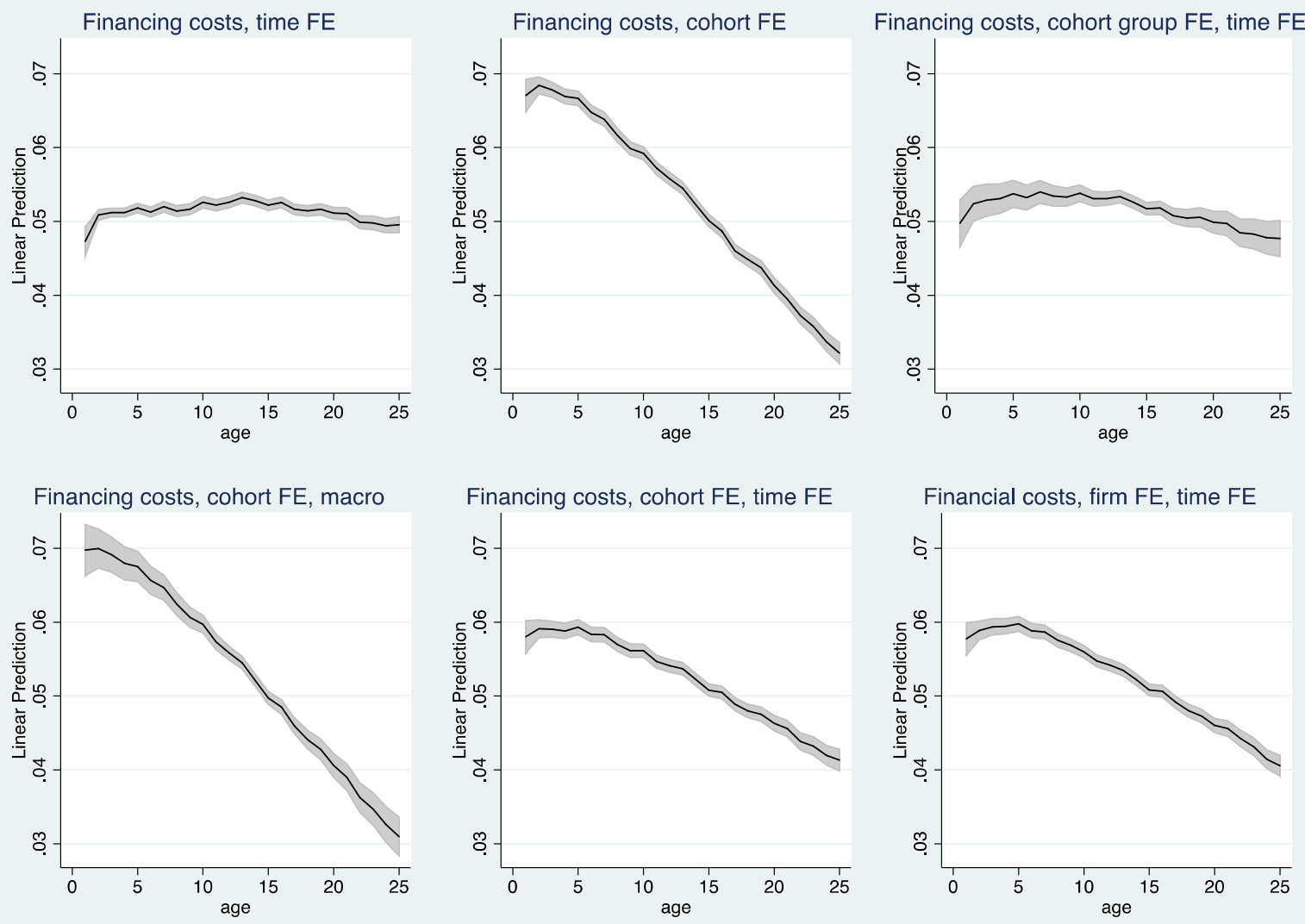

Figure A 1 Life-cycle profiles of financing costs (2005-2013) (defaults and bankruptcies)

The figures show the fitted life-cycle profiles of financing costs and associated $95 \%$ confidence intervals from the panel regressions over the 2005-2013 period. The models include firm age dummies and the following controls: $\ln ($ Sales), Tangibility, Profitability, Credit score,

Default and Bankruptcy. In addition, two-digit-level industry dummies and two-digit zip-code-level regional dummies are included in specifications 1-5. The models with the following additional controls are estimated: 1) time fixed effects 2) cohort fixed effects 3 ) cohort fixed effects (birth years grouped at the four-year level) and time fixed effects 4) cohort fixed effects and macro controls 5) cohort and time fixed effects 6) firm and time fixed effects. 

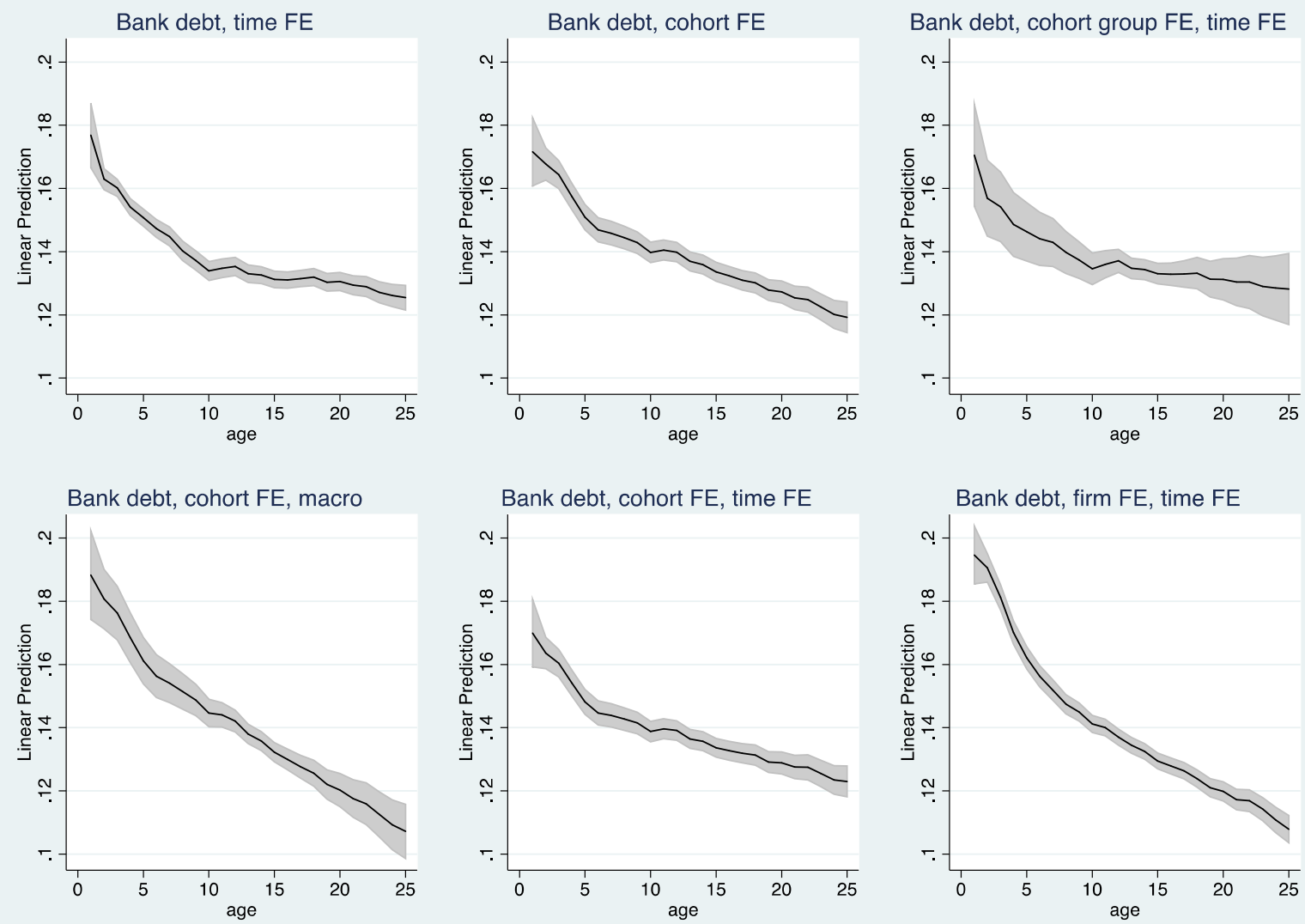

Figure A 2 Life-cycle profiles of bank debt (2005-2013) (defaults and bankruptcies)

The figures show the fitted life-cycle profiles of bank debt and associated 95\% confidence intervals for the panel regressions over the 2005 -

2013 period. The models include firm age dummies and the following controls: $\ln ($ Sales), Tangibility, Profitability, Credit score, Default and Bankruptcy. In addition, two-digit-level industry dummies and two-digit zip-code-level regional dummies are included in specifications 1-5. The models with the following additional controls are estimated: 1) time fixed effects 2) cohort fixed effects 3) cohort fixed effects (birth years grouped at the four-year level) and time fixed effects 4) cohort fixed effects and macro controls 5) cohort and time fixed effects 6) firm and time fixed effects. 